\title{
Review \\ The Role of Oncogenes and Redox Signaling in the Regulation of PD-L1 in Cancer
}

\author{
Christophe Glorieux*(D), Xiaojun Xia and Peng Huang (D)
}

Citation: Glorieux, C.; Xia, X.; Huang, P. The Role of Oncogenes and Redox Signaling in the Regulation of PD-L1 in Cancer. Cancers 2021, 13, 4426. https://doi.org/10.3390/ cancers 13174426

Academic Editor: David Wong

Received: 9 June 2021

Accepted: 16 August 2021

Published: 2 September 2021

Publisher's Note: MDPI stays neutral with regard to jurisdictional claims in published maps and institutional affiliations.

Copyright: (C) 2021 by the authors. Licensee MDPI, Basel, Switzerland. This article is an open access article distributed under the terms and conditions of the Creative Commons Attribution (CC BY) license (https:/ / creativecommons.org/licenses/by/ $4.0 /)$.
State Key Laboratory of Oncology in South China, Collaborative Innovation Center for Cancer Medicine, Sun Yat-sen University Cancer Center, Guangzhou 510060, China; xiaxj@sysucc.org.cn (X.X.); huangpeng@sysucc.org.cn (P.H.)

* Correspondence: christophe@sysucc.org.cn

Simple Summary: PD-L1 is an important immune checkpoint molecule that is expressed in cancer tissues at various levels and plays a major role in tumor evasion from immune system. Therefore, understanding the mechanisms by which PD-L1 expression is regulated in tumor environment is important for the design of new therapeutic strategies to overcome tumor immune escape and improve the outcome of cancer treatment. Recent studies suggest that genetic, epigenetic, and transcriptional factors as well as posttranscriptional and posttranslational processes are crucial regulators of PD-L1 expression in tumor cells. This review focuses on two newly described regulations of PD-L1 mediated by oncogenes, and redox homeostasis. In this context, a recent research work describes the important role of oncogenic K-ras, growth factor receptors (FGFR1 and EGFR) and ROS in regulating PD-L1 expression in pancreatic cancer cells and aids significant new mechanistic insights in this important area.

Abstract: Tumor cells can evade the immune system via multiple mechanisms, including the dysregulation of the immune checkpoint signaling. These signaling molecules are important factors that can either stimulate or inhibit tumor immune response. Under normal physiological conditions, the interaction between programmed cell death ligand 1 (PD-L1) and its receptor, programmed cell death 1 (PD-1), negatively regulates T cell function. In cancer cells, high expression of PD-L1 plays a key role in cancer evasion of the immune surveillance and seems to be correlated with clinical response to immunotherapy. As such, it is important to understand various mechanisms by which PD-L1 is regulated. In this review article, we provide an up-to-date review of the different mechanisms that regulate PD-L1 expression in cancer. We will focus on the roles of oncogenic signals (c-Myc, EML4-ALK, K-ras and p53 mutants), growth factor receptors (EGFR and FGFR), and redox signaling in the regulation of PD-L1 expression and discuss their clinical relevance and therapeutic implications. These oncogenic signalings have common and distinct regulatory mechanisms and can also cooperatively control tumor PD-L1 expression. Finally, strategies to target PD-L1 expression in tumor microenvironment including combination therapies will be also discussed.

Keywords: PD-L1; oncogenes; growth factors; ROS; redox homeostasis; cancer; combination therapy

\section{Introduction}

The discovery of molecules that act as regulators of the immune system opened a new area in tumor therapy. James Allison, recipient of the 2018 Nobel prize, and his colleagues pioneered the concept of immunotherapy for cancer targeting these "immune checkpoints". In 1996, they demonstrated that the in vivo administration of antibodies against CTLA-4 (cytotoxic T-lymphocyte-associated protein 4) resulted in tumor rejection [1], and was termed the so-called "checkpoint blockade immunotherapies". Ipilimumab (an anti-CTLA-4 antibody) was the first approved checkpoint blockade immunotherapy by the American Food and Drug Administration (FDA) in March 2011 for the treatment of advanced melanoma. 
Among important immune checkpoints, PD-1 (programmed cell death-1) is a molecule expressed on T cells that was discovered by Nobel prize winner Tasuku Honjo's team in 1992 [2]. Later in the 90s, the first ligand of PD-1 receptor was discovered and named PD-L1 (programmed cell death ligand 1), also known as CD274 or B7-H1 [3,4]. A few years later, PD-L2 was reported as a novel PD-1 ligand [5]. The interaction between PD-1 and its ligands induces inhibition of $\mathrm{T}$ cells and prevents autoimmunity $[4,6]$. Based on these findings, PD-L1 antibodies were tested as immune checkpoint blockade. Iwai et al. demonstrated that tumor PD-L1 expression was a novel mechanism of immune escape and blocking the interaction of PD-1/PD-L1 led to tumor regression in several murine tumor models [7]. Given the importance of these molecules for tumor immunity, efforts were made to establish the regulation of their expression and to find better combination therapy in order to kill resistant tumors.

\section{Structure of Human PD-L1 and Evolution}

Since PD-L1 plays an important role in immunity, it was not surprising that no equivalent protein was found in prokaryotes, plants, and primitive eukaryotes. Human PD-L1 is composed of 290 amino acids, shares $40 \%$ amino acid identity with human PD-L2 and $70 \%$ with its murine ortholog [8]. PD-L1 is a type I transmembrane glycoprotein composed of immunoglobulin-type extracellular domains, a short intramembrane domain, and cytoplasmic tail [9]. All members of the B7 family are predicted to dimerize but it is still uncertain whether PD-L1 could form such homodimers on the cell surface $[10,11]$. The intracellular domain is very short (length, 30 amino acids) and is highly conserved among species. No biological function and no motif for signal transduction were reported for this protein sequence [12]. The extracellular region is composed of two domains spaced by a short linker sequence. From the cytoplasmic membrane to the $\mathrm{N}$-terminus, there is an IgG (immunoglobulin)-like C2 type domain and an IgG-like V type domain [9]. This latter is composed of $\beta$ strands and mainly interacts with PD- 1 receptor and antagonistic antibodies [9,11].

\section{Tissue Distribution and Subcellular Localization}

In various human tissues, the highest PD-L1 mRNA levels were found in the placenta, heart, thymus, and lung. Lower PD-L1 expression was found in the kidneys, spleen, and liver while PD-L1 mRNA was nearly undetectable in the brain, colon, small intestine, testes, and ovary $[3,4,13]$. In the human digestive system, PD-L1 mRNA levels were higher in tumor tissues than in their respective controls. Conversely, pancreas and colon control tissues had higher PD-L1 mRNA expression [14]. However, the PD-L1 mRNA and protein levels do not always correlate in human and mouse tissues $[15,16]$. This discrepancy may be explained by the complex regulation of PD-L1 and is further discussed in this review (Section "Regulation of PD-L1 in cancerous tissues").

PD-L1 is expressed on the cell surface of antigen-presenting cells including dendritic cells and macrophages upon stimulation [17-19]. PD-L1 can be also present on activated T and B cells while absent on resting cells [3]. Besides immune cells, PD-L1 can be expressed by fibroblasts [20,21], epithelial [22-24], and stromal cells [25]. PD-L1 expression on these cells may also play a critical role in tumorigenesis and participate in immune escape of tumor cells [26-29]. In addition, PD-L1 was detected in various tumor tissues and tumor cell lines.

Since its receptor is a membrane protein, PD-L1 was first detected on the cell surface of immune cells [3,4]. Through immunoblotting and immunocytochemistry analyses, PD-L1 was localized in the cytoplasm and nucleus of various cancer cells. This aberrant expression of PD-L1 correlated with poor prognosis in colon [30], thyroid [31], and esophageal carcinoma [32]. In breast cancer cells, doxorubicin-induced nuclear PD-L1 translocation and acted as an anti-apoptotic molecule [33]. Moreover, transfection of K562 leukemia cells with a splicing variant lacking $\mathrm{IgV}$ domain also showed nuclear and cytoplasmic subcellular localization while membrane localization was observed in cells transfected 
with wild-type protein [34]. It would be interesting to investigate the proportion of spliced variants and whether anthracyclines might induce splicing of PD-L1 mRNA in cancer cells. However, Polioudaki et al. demonstrated that PD-L1 expression in the cytoplasm or nucleus might be an artifact due to inappropriate sample treatment [35]. Thus, the non-membrane localization of PD-L1 remains to be further investigated.

\section{Biological Functions and Related Diseases}

In order to understand the biological functions of PD-L1, the biological changes in PD-1 expressing cells were investigated because PD-L1 has no intrinsic signaling when engaged with its receptor. Upon its discovery, Dong et al. reported B7-H1 (PD-L1) as a costimulatory molecule but the related mechanisms are still obscure [3]. Freeman and colleagues then demonstrated that the interaction of PD-L1 with its receptor mostly triggered inhibitory signaling in T cells [4]. Indeed, incubation of PD- ${ }^{+}$T cells with PD-L1/IgG fusion protein resulted in a decreased proliferation and production of effector cytokine molecules such as interferon-gamma (IFN $\gamma$ ) and interleukin-10 (IL-10) [4]. Studies with PD-1 KO mice further indicated the negative signaling after PD-1/PD-L1 interaction [4]. Similar findings were then observed with T cells from PD-L1 KO mice [36]. Moreover, the proliferation of splenic T cells from PD-1 KO mice was not inhibited when incubated with the PD-L1/IgG fusion protein [4]. Blocking PD-L1/PD-1 interaction in various cell types by using PD-L1 antibodies also supports the negative PD-1 signaling in T cells [7,17,37-40]. As PD-1 signaling inhibits $T$ cell function, it was not surprising to observe a correlation between PD-1 or its ligands with autoimmune or other immunological diseases. Indeed, the deletion of PD-1 gene in mice was found to induce lupus-like phenotype [41], cardiomyopathy [42], and type I diabetes [43]. In humans, polymorphism of PD-1 and PD-L1 was found to correlate with the appearance of autoimmune diseases [8]. Several lines of evidence have also demonstrated the PD-1/PD-L1 axis as playing a pivotal role in immunological tolerance, feto-maternal tolerance, transplantation immunity, and against infectious diseases [8]. Finally, PD-L1 expression in tumor and infiltrated immune cells was reported as an immune escape mechanism. Indeed, PD-L1 KO mice bearing MC38 colon tumors achieved tumor regressions [44] and checkpoint blockade showed strong therapeutic activity in multiple corresponding models [7].

\section{Regulation of PD-L1 in Cancerous Tissues}

\subsection{PD-L1 Expression in Cancers and Role in Tumorigenesis}

As previously described, PD-L1 was detected in multiple types of cancers and its expression has been associated with a general mechanism of immune escape [45]. Indeed, PD-L1 expressed by tumor cells can interact with PD-1 receptor and thus lead to T cell inactivation and immunosuppression. Immune escape is now considered as a major hallmark of tumors [46]. The crucial role of PD-1/PD-L1 interaction in the tumor environment and immune escape was demonstrated when the disruption of this interaction by antagonistic antibodies led to tumor regression in many animal models [7] and was further confirmed by successful clinical trials with PD-1/PD-L1 antagonistic antibodies [47]. Consistent with these findings, a positive correlation was found between high PD-L1 tumor expression and poor prognosis in most cancer types [48]. However, the role of PD-L1 in tumor immune response seems rather complex. Although intratumoral PD-L1 expression by immunohistochemistry staining was approved by FDA as a prediction factor for anti-PD-1 therapy response, PD-L1 has been found in some studies to have no significant predictive value in predicting clinical responses to immunotherapies in numerous studies [49-52]. As such, the prognostic value of PD-L1 expression in predicting clinical response to immune checkpoint blockades remains debatable and predicting responses to immunotherapy is still a major challenge. In the clinical situation, blocking PD-1/PD-L1 interaction exhibited significant therapeutic effects for tumors such as melanomas and lung cancers [53]. However, treatment regimens including PD-1/PD-L1 antibodies as monotherapy or in combination with standard therapies failed to care for patients suffering from pancreatic [54] or colon 
cancer [55], leading to recurrence [56]. Moreover, chemotherapies may induce elevated PD-L1 expression in tumor cells [57]. The complex role of PD-L1 is further illustrated by its co-regulation with immune responses such as IFN $\gamma$ and antigen stimulation. PD-L1 may function as a negative regulator of immune response and inflammation occurs in conjunction to the cellular sensing and response to these external cues. In this case, PD-L1 is associated with "hot" tumor microenvironment and immune-responding cancer cells. Moreover, PD-L1 could function as a secondary resistance mechanism in immune-rich tumors. Immune-deprived or "cold" tumors, which are more challenging to treat, usually do not exhibit high PD-L1 expression, as there is no selective advantage for cancer cells in expressing it [58]. Major efforts are currently undertaken to understand the mechanisms of resistance and to find better combination treatment. The resistance to immunotherapies could be explained by several mechanisms. Among them, the absence of antigen stimulation signal, expression of other immune checkpoints, the influence of tumor microenvironment, the initial proportion of tumor-infiltrating lymphocytes (TIL), the presence of immunosuppressive cells, and dynamic tumor PD-L1 expression influence the efficacy of immunotherapies [56].

In this context, understanding the detailed mechanism of PD-L1 regulation could be one of the solutions to overcome resistance. The regulation of PD-L1 is very complex and PD-L1 expression can be controlled by multiple mechanisms (Figure 1). Genetic alterations, epigenetics, transcriptional, posttranscriptional, and posttranslational regulations of PD-L1 have been extensively studied and reviewed, and thus, we will only briefly touch on these regulatory mechanisms in the next sections but will focus mostly on their most recent findings; particularly the three newly described regulations of PD-L1 expression mediated by oncogenes, growth factors, and redox homeostasis.

\subsection{Genetic Alterations}

Human CD274 gene (PD-L1) is located on the short arm of chromosome 9 (9p24.1). Seven exons encode the transmembrane, cytoplasmic, and extracellular domains. The promoter has CpG methylation sites along the $5^{\prime}$-untranslated region ( $5^{\prime}$-UTR) and exon 1 , while translation starts from exon 2 [59]. Moreover, different gene variants were recently reported [59]. Gene amplification, loss of heterozygosity, and deletion of chromosomal arms are common genetic alterations detected in tumor cells [60]. Since PD-L1 is often upregulated in tumor tissues, particular attention was given to observe a possible link between its expression and CD274 gene amplification. Amplification of chromosome 9p24.1 in Hodgkin lymphoma and B cell lymphoma was linked to PD-L1 upregulation and its neighbor gene JAK2 (Janus kinase 2), which also induced PD-L1 transcriptional activation [61]. In Hodgkin lymphoma, 36\% had PD-L1/PD-L2 gene amplification and 56\% were characterized by a copy gain [62]. High level of 9p24 amplicon was found in 30\% of triple-negative breast cancer (TNBC), $5 \%$ of glioblastomas, and 3\% of colon carcinomas [63]. However, no association was further observed between PD-L1 expression and copy-number gain status in TNBC [64]. The chromosomal region 9p24 includes the loci for PD-L1, PD-L2 and JAK2. Hence, these molecules are overexpressed in cells harboring a genomic gain and were associated with poor prognosis. Whereas most non-small cell lung cancer (NSCLC) cells lack PD-L1 expression, a subset population $(2 \%)$ was characterized by a genomic gain and was particularly sensitive to immune checkpoint blockade [65]. Moreover, genomic alterations also correlated with PD-L1 expression in NSCLC [66]. Indeed, the copy gain was found to be correlated with high PD-L1 expression, whereas loss of chromosomal arm 9p24 was associated with low PD-L1 expression [65]. Most CD274 gene amplifications are caused by genomic rearrangements and do not affect the open reading frame, thus, leading to high-level expression of PD-L1. Conversely, PD-L1 expression did not always correlate with gene copy number in certain cancers, suggesting that transactivators might be lacking in these tumors. Therefore, immunohistochemistry PD-L1 analyses would better predict response to immunotherapies than comparative genomic hybridization or fluorescence in situ hybridization analyses. 


\section{Transcriptional}

- Signaling pathways (MAPK, AMPK, JAK/ STAT, GSK3/ $\beta$-catenin/ ZEB1, NF-KB) - Transcription factors (YY1, AP-1, HIF-1 $\alpha$ )

- Super-enhancer region - Cytokines (IFNy, type I IFN, TGF- $\beta$, IL-6, GM-CSF) - Oncogenes (FGFR, EGFR, c-Myc, EML4-ALK, p53 and K-ras mutants) - Oxidative stress $\left(\mathrm{H}_{2} \mathrm{O}_{2}\right)$

\section{Translational and post-translational} - PTEN/ PI3K/ Akt (EGFR/ FGFR)

- Protein stability

- Glycosylation (GLT1D1)

- Ubiquitination (CMTM4/6)

- Cyclin D/ CDK4/ cullin-3/ SPOP

\section{Post-transcriptional}

- mRNA stability

- Humoral factors (estrogen)

- TTP and AUF1 (K-ras/ ROS)

- micro-RNAs

\section{PD-L1 expression}
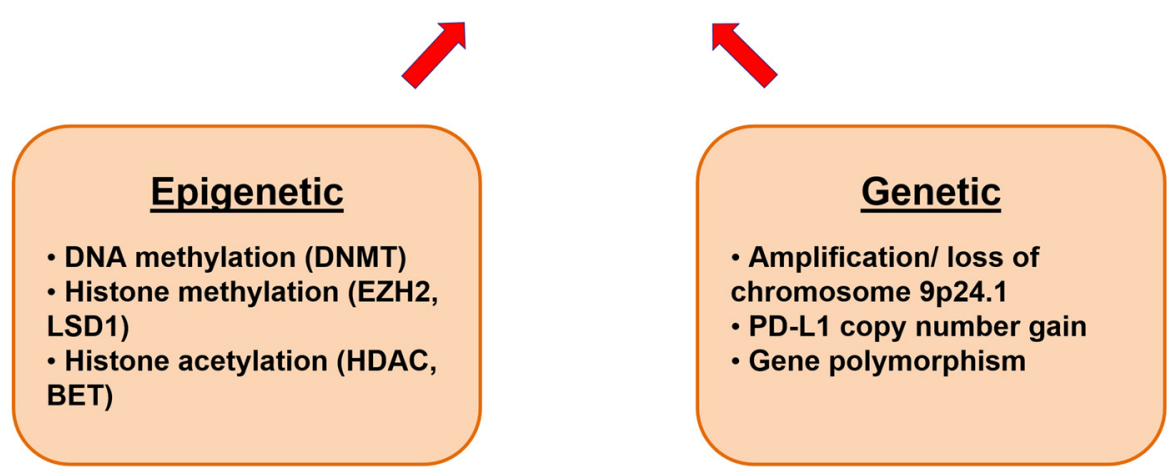

Figure 1. The expression of PD-L1 is regulated at various levels.

Many studies reported a significant effect of PD-L1 polymorphism on patients' outcomes. Studies from Kula et al. on PD-L1 polymorphism showed their influence on cancer stage, effectiveness of chemotherapy, and prognosis after tumor resection [67]. Most of these polymorphisms were located in the promoter region, $3^{\prime}$-UTR ( $3^{\prime}$-untranslated region), and introns. They might alter the binding of transcription factors (i.e., Specific Protein 1) or micro-RNAs, and could influence the expression of PD-L1.

\subsection{Epigenetic Alterations}

Epigenetic modifications can contribute to or prevent carcinogenesis by altering the gene expression profile. In this context, epigenetic changes have been associated with profound modification of PD-L1 expression in cancer cells $[59,68,69]$. DNA methylation and histone acetylation/methylation are the main epigenetic modifications. Five CpG islands were found in the PD-L1 promoter [59] and the quantification of methylated PD-L1 gene was proposed as a prognostic tool [70]. First, the hypomethylation of the PD-L1 promoter was detected in melanoma [71] and this phenomenon was correlated with an interferon signaling phenotype in this type of tumor [72]. The proportion of hypomethylated PD-L1 promoter was increased in primary breast cancer and colorectal cancer [73]. In contrast, Sasidharan Nair et al. did not observe changes in DNA demethylation between normal colon and cancer tissues [74]. Most of these publications provide evidence showing that a combination with epigenetic therapy and immunotherapy could be a promising approach in cancer treatment; considering that prior research targeting DNA methylation and histone methylation have shown improvements in patients' outcomes [75]. Moreover, a strategy 
to increase the methylation of PD-L1, by using fusion protein DNA methyltransferase (DNMT) and Zinc finger domain that binds PD-L1 promoter, decreased PD-L1 function in prostate cancer cells [76]. Although DNMT inhibitors tend to increase PD-L1 levels in most studies, decitabine and quisinostat decreased PD-L1 expression in multiple myeloma [77].

In addition to the change in DNA methylation pattern, PD-L1 expression is tightly regulated by histone methylation or acetylation, modifying chromatin remodeling and therefore gene expression. Indeed, the EZH2 (enhancer of zeste homolog 2), LSD1 (lysinespecific demethylase 1), BET (bromo- and extra-terminal domain) family members, and HDAC (histone acetylases) were found involved in this regulatory process. EZH2 is a subunit of the polycomb repressive complex 2 and a histone methyltransferase. This enzyme mediates gene repression by increasing tri-methylated H3K27 levels around target genes. EZH2 activity correlated with PD-L1 downregulation in hepatocarcinoma [78] and was dependent on the HIF-1 $\alpha$ (hypoxia-inducible factor 1 alpha) activation in lung cancer [79]. BET family members are a class of epigenetic readers that bind acetylated histones and facilitate the recruitment of co-activators complexes. The BET inhibitor JQ1 repressed PD-L1 gene transcription in prostate cancer and potentiated with anti-CTLA-4 [80]. Moreover, JQ1 was associated with decreased PD-L1 expression in nasopharyngeal cancer [81] and oral squamous cell carcinoma [82]. Another BET inhibitor, PLXS1107, showed similar effects and potentiated immunotherapy in melanoma [83]. In pancreatic stellate cells, BET inhibition was directly linked to the IFN $\gamma$-mediated PD-L1 expression [84]. HDAC3 silencing led to a decreased DNMT1 expression, PD-L1 upregulation, and potentiated PD-L1 antibody [85]. HDAC inhibitors showed similar effects and synergized with PD-1/PD-L1 checkpoint blockade [86]. Conversely, HDAC6 was found to be positively correlated with PD-L1 expression, suggesting a histone-independent mechanism [87]. Nevertheless, HDAC6 inhibition sensitized ovarian tumors to anti-PD-L1 therapy [88]. LSD1 has histone demethylase activity and acts as a transcriptional activator. In triple-negative breast cancer, LSD1 was inversely correlated with PD-L1 expression [89].

\subsection{Signaling Pathways and Transcriptional Regulation}

The involvement of signaling pathway activation and the role of transcription factors were investigated in regard to PD-L1 regulation in cancer cells. The first signaling pathway to be reported as a PD-L1 regulator was Akt/PKB (protein kinase B). This study suggested that a loss of PTEN (phosphatase and tensin homolog) subsequently activated PI3K (phosphoinositide 3-kinase)/Akt signaling and PD-L1 upregulation in glioma [90]. These findings were further confirmed in other models [91,92] and the Akt-mediated mechanism was mostly related to PD-L1 protein stability rather than transcriptional regulation. Akt is mainly activated through receptor tyrosine kinases such as EGFR (epidermal growth factor receptor) and FGFR1 (fibroblast growth factor receptor 1) and are further discussed below.

Activated by different sources of stimuli, the MAPK (mitogen-activated protein kinase) [93,94], AMPK (adenosine 5'-monophosphate (AMP)-activated protein kinase) [95], JAK/STAT (signal transducer and activator of transcription) [96,97], GSK3 (glycogen synthase kinase-3) / $\beta$-catenin/ZEB1 (zinc finger E-box binding homeobox 1) [98], and NF- $\mathrm{B}$ (nuclear factor kappa-B) $[99,100]$ pathways are also able to control PD-L1 gene expression. They may crosstalk to control PD-L1 expression [101]. In addition, several transcription factors are known to bind to PD-L1 promoter and regulate its transcriptional activity. Indeed, Myc (Myc proto-oncogene) [102], STAT3 [103], NF-кB [99], YY1 (Yin Yang 1) [104], and AP-1 (activator protein 1) $[105,106]$ were found to bind the promoter and positively regulate PD-L1 expression in cancer cells. Moreover, tumor microenvironment conditions such as hypoxia were found to enhance PD-L1 expression [107] and HIF-1 $\alpha$ could directly bind to the promoter to control its expression [108]. Recently, a super-enhancer region was identified in PD-L1 and PD-L2 promoters and could be potentially responsible for tumor immune escape [109]. 


\subsection{Posttranscriptional and Posttranslational Regulations}

Although these changes in PD-L1 mRNA levels can be imputed to gene transcription regulation, many studies have demonstrated that PD-L1 could be regulated at the posttranscriptional level. After treatment with actinomycin D, the half-life of PD-L1 mRNA was about $3 \mathrm{~h}$ in MDA-MB-231 [110] and HeLa cells [111]. In these two studies, TTP (tristetraprolin) and AUF1 (AU-rich element-binding protein 1) bounded to $3^{\prime}$-UTR and modulated mRNA stability. 5'-UTR and $3^{\prime}$-UTR of PD-L1 mRNA possess many regulatory elements. A plethora of micro-RNAs can, directly or indirectly, alter PD-L1 expression in cancer and immune cells by interacting with these regulatory sequences [112].

The $N$-glycosylation is the most important posttranslational modification (PTM) for PD-L1 and can lead to protein stabilization and immunosuppression [113]. Indeed, the halflife of glycosylated PD-L1 was about $12 \mathrm{~h}$ whereas the non-glycosylated form was about $4 \mathrm{~h}$. Targeting PD-L1 glycosylation with monoclonal antibodies [114] or the glycosyltransferase GLT1D1 (glycosyltransferase 1 domain containing 1) [115] has been found to enhance tumor immune response in TNBC and B cell lymphoma, respectively. Other modifications such as phosphorylation, ubiquitination, and palmitoylation were also reported $[69,116]$ but the characterization of these PTM still remains to be elucidated. In this context, CMTM4/6 (chemokine-like factor-like MARVEL transmembrane domain-containing family member 4/6) protects PD-L1 from ubiquitination and degradation in various cancer cell lines and dendritic cells [117]. In addition, Zhang et al. demonstrated that cyclin D and CDK4 (cyclin-dependent kinase 4) could destabilize PD-L1 protein via cullin-3/SPOP (Speckle type BTB/POZ protein)-dependent mechanism [118].

Akt pathway is one of the primary signaling pathways to regulate PD-L1 expression and was first documented to upregulate PD-L1 expression through translation regulation [90]. Many reports support such regulation, but the underlying regulatory mechanisms are still unknown. Recently, estrogen was found to stabilize PD-L1 mRNA in cancer cells via an Akt-dependent activation [119].

Regarding PD-L1 protein stability, metformin, in combination with immunotherapy, demonstrated promising therapeutic activity by inhibiting PD-L1 through an AMPKdependent mechanism and ER (endoplasmic reticulum)-associated degradation $[95,120]$.

\subsection{Cytokines}

Since immune cells are mainly stimulated or inhibited by secreted factors or by cellcell contact, many studies investigated the role of such extracellular proteins in order to regulate PD-L1 expression. Freeman et al. demonstrated that IFN $\gamma$ could upregulate PD-L1 in monocytes and dendritic cells [4]. A few years later, it was reported that IFN $\gamma$ also stimulated PD-L1 expression in hepatoma cancer cells [34]. It was suggested that high production of IFN $\gamma$ (secreted by cytolytic $\mathrm{CD} 8^{+} \mathrm{T}$ cells, Natural killer, and effector CD4 ${ }^{+}$ $\mathrm{T}$ cells) had antitumor effects while low IFN $\gamma$ levels upregulated PD-L1 and triggered immune evasion [34]. Many reports further demonstrated the role of IFN $\gamma$ in upregulating PD-L1 in cancer cells and other cell types [100,121,122], mainly through JAK/STAT activation [96].

Other cytokines are able to stimulate PD-L1 expression. Indeed, IFN $\gamma$ and TNF $\alpha$ (tumor necrosis factor-alpha) can together activate NF-KB and PD-L1 expression in blasts of myelodysplastic syndromes [100]. Type I IFN can also positively control PD-L1 expression in myeloid-derived suppressor cells [123] and transforming growth factor-beta (TGF- $\beta$ ) induced PD-L1 expression in dendritic cells [124]. Moreover, interleukin-6 (IL-6) [125] and granulocyte-macrophage colony-stimulating factor (GM-CSF) [126] are also able to upregulate PD-L1 in stroma cells.

While the role of cytokines is well established, growing evidence showed growth factors and their receptors also played an important role in immune escape and tumor progression. In the following sections, we are to focus on the roles played by EGFR and FGFR receptors. 


\subsection{Oncogenes}

The presence of activated oncogenes seems to reduce the clinical response to immune checkpoint inhibitors in some studies [127]. In this context, studies that examined a putative link between PD-L1 expression, oncogenic proteins and patient survival led to confusing and discordant conclusions. For example, bioinformatics analyses mainly compare mRNA levels among different tissues and cancer types. Given that PD-L1 expression may be regulated at the translational level, findings obtained by such databases are therefore difficult to interpret. In this context, immunohistochemistry analyses may be more reliable, but such analyses remain semi-quantitative and artifacts or many unknown factors could explain a change in PD-L1 protein levels. We thereby discuss publications that showed strong evidence that oncogenes control PD-L1 expression in cancer cells and the related regulatory mechanisms.

\subsubsection{Fibroblast Growth Factor Receptors}

In regard to the FGFR-mediated PD-L1 regulation (Figure 2), McNiel and Tsichlis first identified a positive correlation between FGF2, FGFR1, Akt3 and immune checkpoints (CTLA-4, PD-1 and PD-L1) in bladder carcinoma [128]. Later, a correlation between FGFR2 and PD-L1 was found in colorectal cancer [129]. FGF7 bound to FGFR2 in SW480 cells and induced $P D-L 1$ gene transcription through JAK-STAT activation. Consistent with these findings, lung tumors expressing mutant FGFR2 or K-ras (Kirsten ras GTPase) exhibited an increase in PD-L1 levels [130]. In this study, the pan-FGFR inhibitor erdafitinib decreased PD-L1 protein levels, increased $\mathrm{CD}^{+} \mathrm{T}$ cell infiltration, and synergized with PD-1 antibody. Moreover, ODM-203, a potent inhibitor of FGFR and VEGFR (vascular endothelial growth factor receptor), was associated with an increased number of intratumoral CD8 ${ }^{+}$ $\mathrm{T}$ cells and NK cells [131]. In line with these results, VEGF and basic FGF inhibited the secretion of IFN $\gamma$ (interferon gamma) and granzyme B by T cells [132]. Lenvatinib, another VEGFR and FGFR inhibitor, was able to reverse the immunosuppressive effect mediated by growth factors and synergized with anti-PD-1 antibody in a colon cancer model. Finally, FGF1/2 bound to FGFR1 and induced PD-L1 mRNA and protein levels in pancreatic cancer cells [133]. A positive correlation was also found between FGFR1 and PD-L1 in pancreatic cancer tissues. FGFR1 activation stimulated Akt/PKB pathway and led to protein stabilization. For now, mechanisms that explained FGFR1-mediated $P D-L 1$ gene transcription are unknown and most of the known regulators (i.e., STAT3) were excluded. The FGFR1 inhibitor PD173074 also decreased PD-L1 protein levels, but not mRNA levels, in in vitro and in vivo mouse pancreatic tumor models. Human and mouse FGFR1 KO cell lines exhibited lower PD-L1 expression compared to wild-type cells. Moreover, mouse pancreatic FGFR1 KO tumors grew slower due to PD-L1 downregulation and an increase in intratumoral $\mathrm{CD}^{+} \mathrm{T}$ cells. Consistent with these findings, FGFR1 KO breast cancer-bearing mice exhibited a higher proportion of intratumoral CD $8^{+} \mathrm{T}$ cells, a lower number of myeloid-derived suppressor cells (MSDC), and became more sensitive to PD-L1 antibody [134]. Moreover, the covalent FGFR inhibitor FIIN4 demonstrated similar effects with FGFR1 KO cells. In concordance with these findings, $40 \%$ of colorectal cancers have mutant K-ras and therefore oncogenic signals might alter FGFR1 and FGFR2 activities to enhance immunosuppression. 


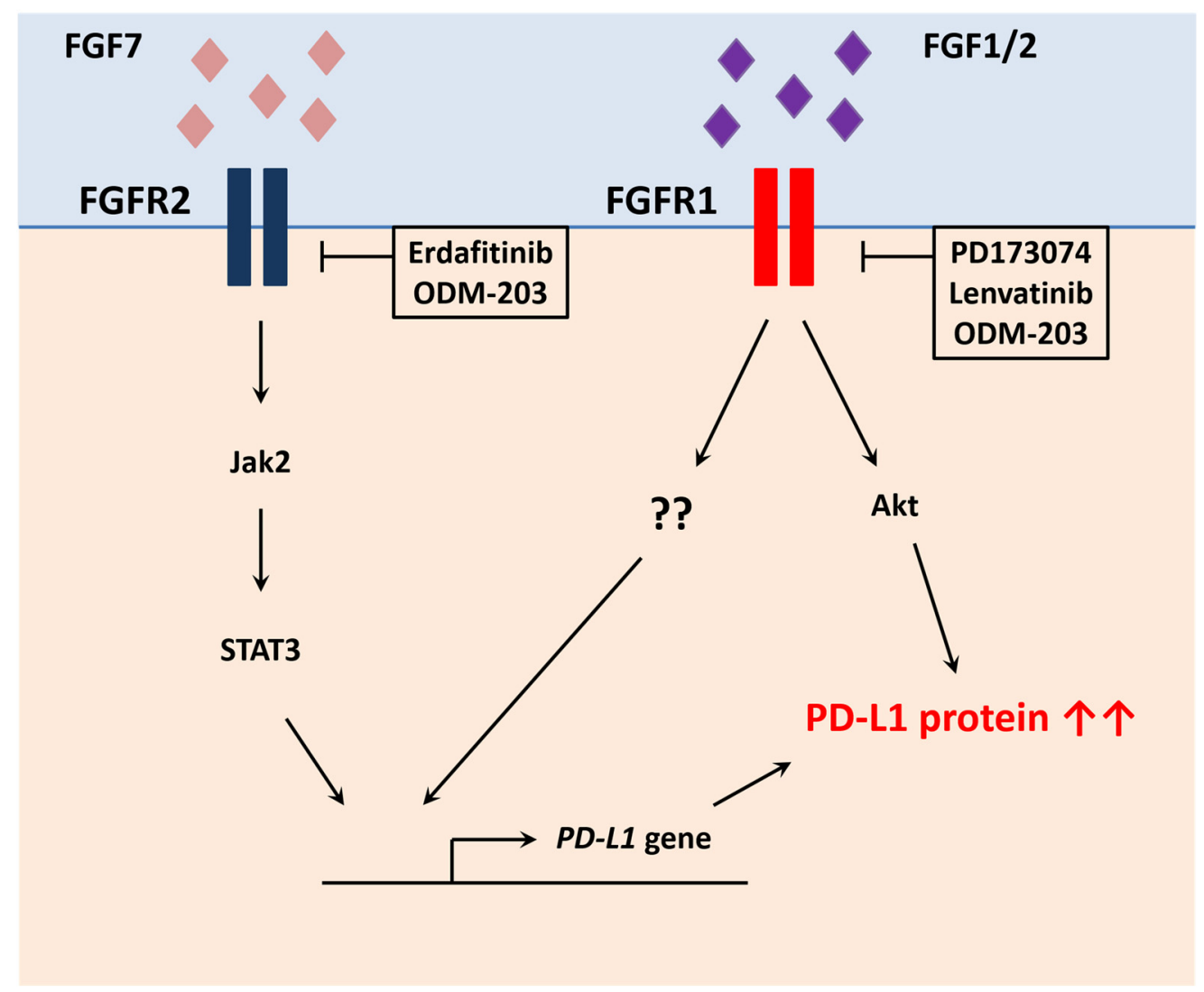

Figure 2. FGFR member family members positively regulate PD-L1 expression in cancer cells. FGFR1 signaling activates Akt signaling and PD-L1 stabilization. FGFR1 also enhances PD-L1 gene transcription by a yet to be discovered mechanism. FGFR2 activates Jak2/STAT3 signaling, which in turn causes PD-L1 upregulation the transcriptional level in cancer cells.

In clinical trials, immune checkpoint blockades have limited efficacy in luminal subtypes of urothelial cancer with FGFR3 mutations. Only a small proportion of patients with FGFR alterations responded to initial PD-1/PD-L1 inhibitors [135]. It was also demonstrated that FGFR3 mutation status was not a biomarker of resistance to immunotherapy in metastatic urothelial cancer [136]. Since the FGFR-dependent regulation of PD-L1 expression was discovered only recently, there has been no report on a putative link between FGFR1/2 mutation status or overexpression and response to PD-1/PD-L1 inhibitors. Currently, there is no data showing a direct correlation between mutant FGFRs and PD-L1 expression. It would be interesting to investigate the possibility that such mutants might affect the expression of PD-L1 in cancer cells. Further studies are therefore needed to elucidate the role of FGFRs in modulating tumor immune response. Interestingly, combination of FGFR inhibitors and immunotherapy showed promising therapeutic effect in multiple solid tumors in clinical trials [137-139], and the underlying mechanisms of action still need to be fully understood.

\subsubsection{Epidermal Growth Factor Receptor}

Figure 3 shows the role of other oncogenes to regulate PD-L1 expression in cancer cells including c-Myc, p53, EML4-ALK, K-ras and EGFR. 


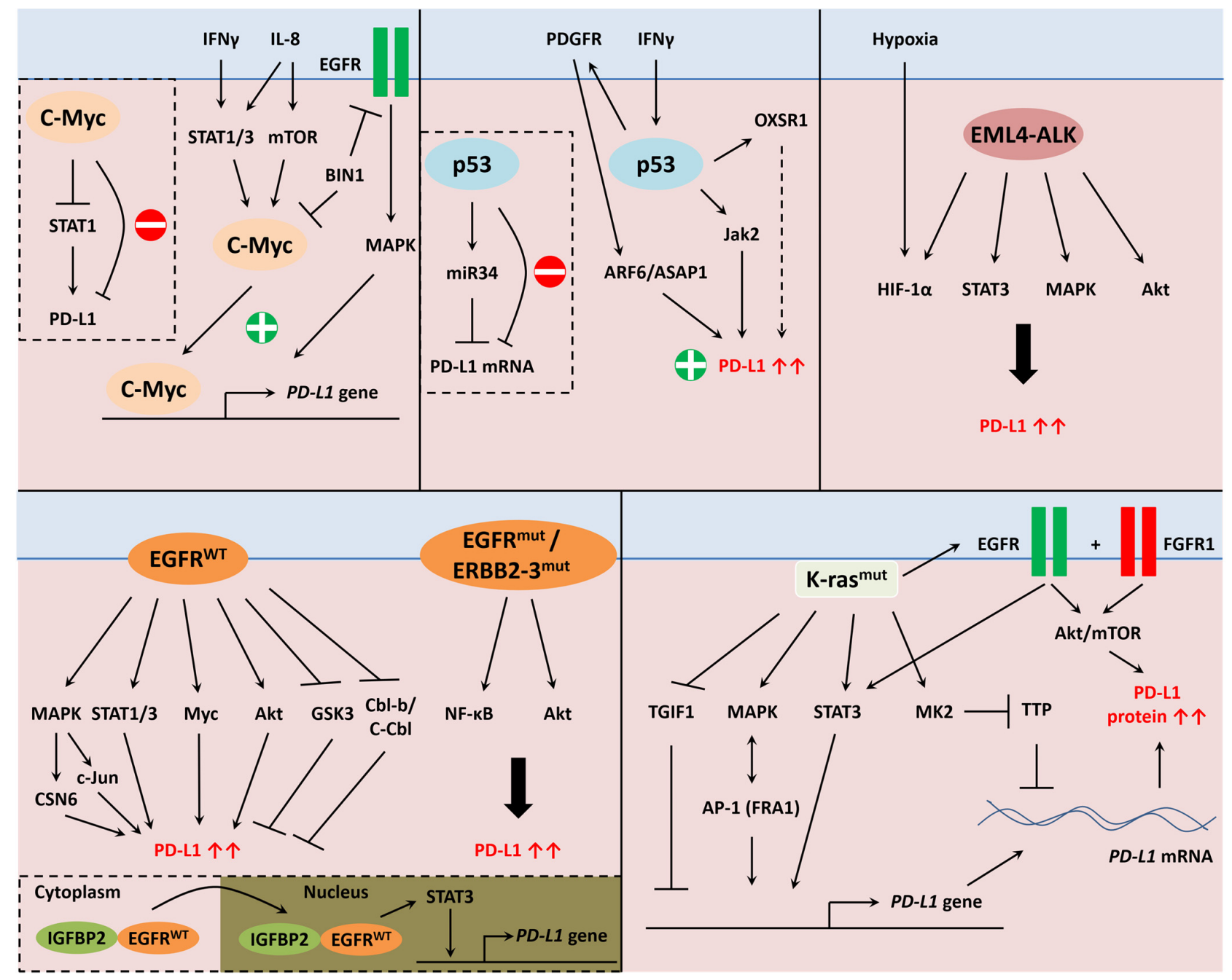

Figure 3. Oncogenic regulation of PD-L1 in cancer cells. Oncogenes including c-Myc, p53, EML4-ALK fusion gene, EGFR, and K-ras regulate PD-L1 expression, positively or negatively, by various and distinct mechanisms.

The first evidence that demonstrated the crucial role of growth factors to control PD-L1 expression was revealed in mutant EGFR NSCLC [140]. In that study, the EGFR inhibitor, gefitinib, was able to decrease PD-L1 cell surface expression. Most of the results were obtained in lung cancer models because EGFR is often mutated in this cancer type. By using exogenous EGF and pharmacological inhibition of EGFR, it was shown that EGFR could control PD-L1 expression through a MAPK/Akt/STAT-dependent mechanism in NSCLC [141-145]. MAPK also increased PD-L1 mRNA levels [143]. The E3 ubiquitin ligases $\mathrm{Cbl}-\mathrm{b}$ (Casitas B-lineage lymphoma proto-oncogene-b) and c-Cbl (Cbl proto-oncogene C) inhibited PD-L1 by inactivating STAT, AKT, and ERK signaling pathways [144]. Moreover, the EGFR inhibitor osimertinib suppressed PD-L1 expression at the posttranslational level via a GSK3-dependent mechanism [146].

In addition to observations in lung cancer, EGFR has also been found to activate the MAPK/Akt/STAT/Myc signaling pathways to upregulate PD-L1 expression in head and neck [147], esophageal [148,149], gastric [150], salivary adenoid cystic carcinoma [151] and EGFR-positive cancers [152]. IGFBP2 (insulin-like growth factor binding protein 2) activated STAT3 phosphorylation by co-localizing with cytoplasmic EGFR. This association facilitated EGFR nuclear accumulation and activated EGFR phosphorylation. The recruitment of STAT3 to the PD-L1 promoter induced its transcriptional activation in melanoma [153]. EGFR activation enhanced CSN6 (COP9 signalosome 6) expression in a MAPK-dependent manner in glioblastoma. CSN6 inhibited PD-L1 protein degrada- 
tion [154]. Moreover, glutamine deprivation resulted in the activation of EGFR signaling through MAPK and c-Jun to regulate PD-L1 expression in renal cancer cells [155].

Finally, the expressions of EGFR and EGF were increased when mutant K-ras was induced in the 293T-K-ras-inducible system. Incubation with EGF alone was sufficient to increase PD-L1 expression in 293T and pancreatic cancer cell lines. Pharmacological inhibition of EGFR with gefitinib and afatinib abolished the K-ras-mediated PD-L1 upregulation. However, afatinib did not change PD-L1 expression in pancreatic cancer cell lines, suggesting that EGFR is not the main factor responsible for immunosuppression in pancreatic cancer [133].

Akbay et al. first demonstrated that PD-L1 expression was upregulated in mutant EGFR-driven lung cancer and might be also associated with K-ras mutation [140]. As previously described, wild-type EGFR has the ability to control PD-L1 expression. However, other studies reported that mutant EGFR was also involved in the regulation of the immune checkpoint. Indeed, gefitinib and erlotinib inhibitors were found to abolish PD-L1 cell surface expression in mutant EGFR NSCLC [156]. Moreover, gefitinib suppressed NF- $k B$ activation and decreased PD-L1 cell surface expression [157]. Finally, ERBB2/3 mutants activated Akt signaling and augmented PD-L1 expression in gallbladder carcinoma [158].

Finally, NSCLC patients with EGFR mutations show poor response to anti-PD-1/PDL1 treatment [159], and the mechanisms responsible for the lack of response to immunotherapy in such patients still remain unclear and need to be investigated. Moreover, combination of tyrosine kinases inhibitors and immunotherapy did not show synergistic effects in NSCLC patients in recent clinical trials $[160,161]$. Further efforts are therefore needed to evaluate different types of drug combinations, administration sequences, and side effects to identify more effective immunochemotherapy for this subset of patients.

\subsection{3. c-Myc}

Depending on the cellular context, the c-Myc oncogene could be a positive or negative regulator of PD-L1 expression. Durand-Panteix et al. were the first to demonstrate that c-Myc was a strong repressor of PD-L1 in EBV (Epstein-Barr virus)-immortalized B cell via STAT1 inhibition. In these cells, c-Myc mainly blocked PD-L1 surface membrane export by decreasing actin polymerization [162]. In addition, Myc inhibition led to STAT1 activation and an increase in PD-L1 expression induced by IFN $\gamma$ in hepatocarcinoma [163]. When cocultured with T cells, an inverse correlation between c-Myc and PD-L1 was found in diffuse large B cell lymphoma (DLBCL) [164]. Finally, Myc inhibitors increased the expression of the immune checkpoint on tumors and sensitized them to PD-1 antibody [165], and these new findings need further evaluation of such drug combination in clinically relevant settings. Afterward, it was shown that Myc transactivation activity could directly bind to PD-L1 and CD47 promoters [102], and a positive correlation between c-Myc and PD-L1 in B cells was observed [166].

In serous papillary endometrial cancer, STAT1 upregulated c-Myc and PD-L1 protein levels [167]. In addition, STAT3 and c-Myc cooperated to induce PD-L1 in DLBCL [168]. Mesenchymal stem cells secreted IL-8 which in turn activated STAT3 and mTOR (mammalian target of rapamycin), to induce c-Myc and PD-L1 expressions in gastric cancer cells [169]. Bridging integrator-1 (BIN1), a c-Myc adaptor protein, inhibited Myc function and EGFR signaling in NSCLC, therefore suppressing PD-L1 expression [170]. Moreover, c-Myc induced PD-L1 gene transcription in neuroblastoma [171], lung [172], gastric, pancreatic [173], and esophageal [174] cancers. Moreover, Myc synergized with K-ras to induce tumor immunosuppression $[175,176]$. In these studies, Myc was shown to control PD-L1 at transcriptional and translational levels. In this context, a positive correlation was found between Myc and PD-L1 protein but not with mRNA in DLBCL [177]. These data are very interesting because they demonstrated that Myc could directly bind to the promoter and was predicted to have transactivation activity. The Myc-mediated PD-L1 translational regulation still remains to be fully elucidated. Altogether, it is still unclear how Myc might repress or activate $P D-L 1$ gene transcription. The repressor Myc activity on PD-L1 might 
be an indirect effect or Myc might cooperate with other transcription factors and bring corepressor complexes.

Currently, limited information is available regarding the correlation between Myc overexpression and response to PD-1/PD-L1 inhibitors in tumors such as B cell nonHodgkin lymphomas. Further studies are therefore needed to evaluate the possibility of administrating immunotherapies in patients with Myc overexpression.

\subsubsection{Protein $\mathrm{p} 53$}

The protein p53 (protein of $53 \mathrm{kDa}$ ) is usually considered as a tumor suppressor gene but many p53 mutants act as oncogenic proteins [178]. Similar to Myc-mediated regulation, experimental findings suggest a double-faced role of p53. First, the protein p53 was shown to participate in PD-L1 regulation and was first considered as the negative regulator. Indeed, a negative correlation between PD-L1 and p53 was previously shown in hepatocarcinoma [179]. Mechanistically, higher expression of PD-L1 was observed in p53 knockout colon and lung cancer cells. The oncogenic protein regulated the expression of microRNA miR34 that bonded and led to the destruction of PD-L1 mRNA [180]. In line with these findings, wild-type p53 promoted cytotoxic T lymphocytes induced cancer cell death via miR34a and PD-L1 inhibition [181].

However, p53 is also viewed as a positive regulator of PD-L1 expression. Indeed, mutant K-ras and p53 activated ARF6 (ADP Ribosylation Factor 6)-ASAP1 (ArfGAP with SH3 domain, ankyrin repeat, and PH domain 1) axis through PDGFR (platelet-derived growth factor receptor) signaling to control PD-L1 expression in pancreatic cancer cells [182]. The mutant p53 protein was at the origin of the elevated OXSR1 (oxidative stress-responsive kinase 1) expression that positively correlated with PD-L1 and the number of TIL [183]. Moreover, p53 inhibition led to a diminution of IFN $\gamma$-induced PD-L1 upregulation through Jak2 inhibition in melanoma [184]. Obviously, more efforts are needed to decipher the molecular mechanisms, mediated by p53, in regulating PD-L1 expression in cancer cells.

In the clinical context, patients with p53 mutations showed better response to immunotherapy compared to patients harboring wild-type p53 [185], but not all p53 mutations are equal in predicting therapeutic efficacy in patients treated with PD-1/PD-L1 inhibitors [186]. Further studies are needed to understand the mechanisms of resistance of wild-type p53 tumors to immunotherapies. Interestingly, a recent study demonstrated that MDM2 (murine double minute 2) inhibitors could activate p53, induce IFN response and synergize with immunotherapy [187]. This approach could potentially transform cold tumors into hot tumors and need further consideration for clinical study.

\subsubsection{EML4-ALK}

Lung cancer is often characterized by the presence of several oncogenes including mutant EGFR and K-ras. Another frequent anomaly in lung cancer is the EML4-ALK (echinoderm microtubule-associated protein-like 4-anaplastic lymphoma kinase) fusion gene. This oncoprotein has shown the ability to enhance PD-L1 expression. Indeed, EML4-ALK stimulated STAT3 binding activity to elevate PD-L1 expression in pulmonary adenocarcinoma. The expression of the immune checkpoint was further enhanced by HIF$1 \alpha$ binding under hypoxic conditions [188]. Moreover, oncogenic signaling activated MAPK and Akt pathways in order to trigger PD-L1 expression in NSCLC [189]. In these two latter studies, silencing ALK suppressed PD-L1 protein levels. In addition, overexpression of EML4-ALK enhanced PD-L1 expression in NSCLC. Inhibition of ALK, which suppressed MAPK and Akt activation, also led to IFN $\gamma$ production in coculture system with dendritic and T cells [190].

Currently little is known regarding the exact role of EML4-ALK on tumor immune response. A recent retrospective study revealed that approximately $10 \%$ of ALK-positive patients responded to immunotherapies [191]. Combination of ALK inhibitors and immunotherapy seems to show efficacy but some patients developed severe hepatotoxicity, and long-term clinical outcomes have not yet been reported [192,193]. Therefore, further 
studies are needed to identify effective immunotherapy and its combination with chemotherapy to achieve favorable clinical outcome for patients with $A L K$ gene rearrangements.

\subsubsection{K-Ras}

The first evidence that mutant K-ras may regulate PD-L1 was found in NSCLC. In that study, mutant K-ras triggered the activation of MAPK/AP-1/STAT3 signaling in order to induce PD-L1 expression [194]. In line with these findings, mutant K-ras activated MAPK signaling [195] through FRA1 (FOS-related antigen 1) transcriptional activity [196] to augment PD-L1 protein levels in NSCLC. Moreover, higher PD-L1 expression was observed in mutant EGFR and K-ras lung cancer cells through an Akt/mTOR-dependent mechanism [197]. In this same study, PD-L1 expression was higher in mutant K-ras HCT116 colon cancer cells compared to wild-type K-ras HCT116 cells.

In pancreatic cancer cells, K-ras decreased the levels of TGIF1 (TGF- $\beta$ induced factor homeobox 1) which is a nuclear corepressor of PD-L1 gene transcription [198]. Moreover, FGFR1 signaling plays an important role in the K-ras-mediated PD-L1 upregulation. Indeed, exogenous FGF or FGFR1 inhibitors were able to modulate PD-L1 expression in pancreatic cancer cell lines. Moreover, there was a correlation between PD-L1 and FGFR1 expressions in mutant K-ras pancreatic tissues and not in wild-type K-ras cancers [133].

The best proof of the involvement of oncogenic K-ras in this regulation was found in Kras inducible cell systems. By using such in vitro models, oncogenic protein activation was associated with an increase in EGFR and FGFR1 protein levels. Activation of both growth factor receptors stimulated Akt signaling leading to increased PD-L1 mRNA and protein levels [133]. In another in vitro model, K-ras activation led to PD-L1 mRNA stabilization. Mechanistically, K-ras signaling activated the MK2 (MAPK-activated protein kinase 2) enzyme which further inhibited the TTP activity by phosphorylation [199]. Moreover, MAPK enhanced PD-L1 mRNA stability in mutant K-ras NSCLC [143]. Altogether, these data demonstrated a strong immunosuppressive effect mediated by oncogenic signals.

The responses to immunotherapy of NSCLC patients with K-ras mutations are heterogeneous, and it remains difficult to draw solid conclusions because K-ras mutated disease might show different clinical characteristics. Moreover, the co-existence of other genetic events (i.e., mutant p53) may influence response to anti-PD-1/PD-L1 treatment for NSCLC patients [191]. It is worth noting that patients with colorectal cancers with K-ras mutations and pancreatic cancer patients ( $90 \%$ have mutant K-ras) exhibit poor response to immunotherapy $[54,55]$. The mechanisms of resistance to immunotherapy might not only depend on the presence of specific oncogenes or their mutation status but might also be influenced by the unique tumor microenvironment observed in certain tumor types.

\subsection{Redox Regulation of PD-L1}

Tumor cells frequently generate and secrete reactive oxygen species (ROS) and the resulting oxidative stress in the tumor microenvironment is now emerging as a potent PD-L1 inducer. Many studies have reported high PD-L1 expression associated with high generation of ROS but no direct link between these two observations has been investigated [200-207].

Bailly et al. first described the variable effects of ROS-modulating drugs on PDL1 [208]. PD-L1 was found to be regulated by NF- $\mathrm{KB}$ and HIF-1 $\alpha$, which are transcription factors controlled by redox mechanisms. However, these compounds might have multitarget effects and may explain the differential PD-L1 expression during exposure to such pro-oxidant drugs. Since antioxidants such as $\mathrm{N}$-acetyl-cysteine might also have multitarget effects, the use of hydrogen peroxide $\left(\mathrm{H}_{2} \mathrm{O}_{2}\right)$ could be the best proof-of-concept to study the redox regulation of PD-L1 depicted in Figure 4. In this context, $\mathrm{H}_{2} \mathrm{O}_{2}$ enhanced PD-L1 protein in monocytes [209]. During infection to EBV, TLR7/8 (Toll-like receptor 7/8) signaling elevated PD-L1 through MyD88 (myeloid differentiation primary response 88) and IRAK1/4 (interleukin 1 receptor-associated kinase 1/4) signaling. During viral infection, ROS is generated from TLR/MyD88/IRAK signaling because IRAK inhibition 
abolished EBV-mediated PD-L1 upregulation. Moreover, induced oxidative stress was associated with p38 (protein of $38 \mathrm{kDa}$ )/JNK (c-Jun $\mathrm{N}$-terminal kinase)/NF-kB/STAT3 activation to control PD-L1 expression in infected monocytes. It is still unclear how ROS regulates PD-L1 expression in monocytes, possibly through direct activation, indirect activation (via NF- $\mathrm{KB}, \mathrm{MAPK}$ ), induction of $P D-L 1$ gene transcription, or translational regulation. Infection with HHV-6B (human herpesvirus $6 \mathrm{~B}$ ) showed similar findings with elevated ROS levels which in turn stimulated STAT1/3 and PD-L1 [210]. In bone marrowderived macrophages, paclitaxel generated ROS through an unknown mechanism and enhanced the expression of the immune checkpoint. This oxidative stress led to NF- $\mathrm{kB}$ activation and PD-L1 gene transcription [211]. In K-ras-driven cancer cells, $\mathrm{H}_{2} \mathrm{O}_{2}$ or glucose oxidase (an enzyme that generates $\mathrm{H}_{2} \mathrm{O}_{2}$ ) augmented PD-L1 mRNA and protein levels [133]. ROS induced FGFR1 gene transcription by a yet to be discovered mechanism. Moreover, ROS could directly activate this FGFR1 receptor. Generation of $\mathrm{H}_{2} \mathrm{O}_{2}$ cannot induce PDL1 expression in FGFR1 KO cells, suggesting the receptor played a crucial role in this redox regulation. FGFR1 signaling increased PD-L1 protein level through Akt activation. However, the molecular mechanisms of how FGFR1 induced PD-L1 mRNA levels remain to be uncovered. A possible explanation could be that FGFR1 activation might stimulate the binding of transcription factors on the $P D-L 1$ promoter or might stabilize its mRNA. In agreement with this hypothesis, ROS inhibited TTP enzyme activity in mutant K-ras cancer cells [199]. It would be interesting to investigate whether FGFR1 might modulate TTP enzyme activity and PD-L1 mRNA stability.

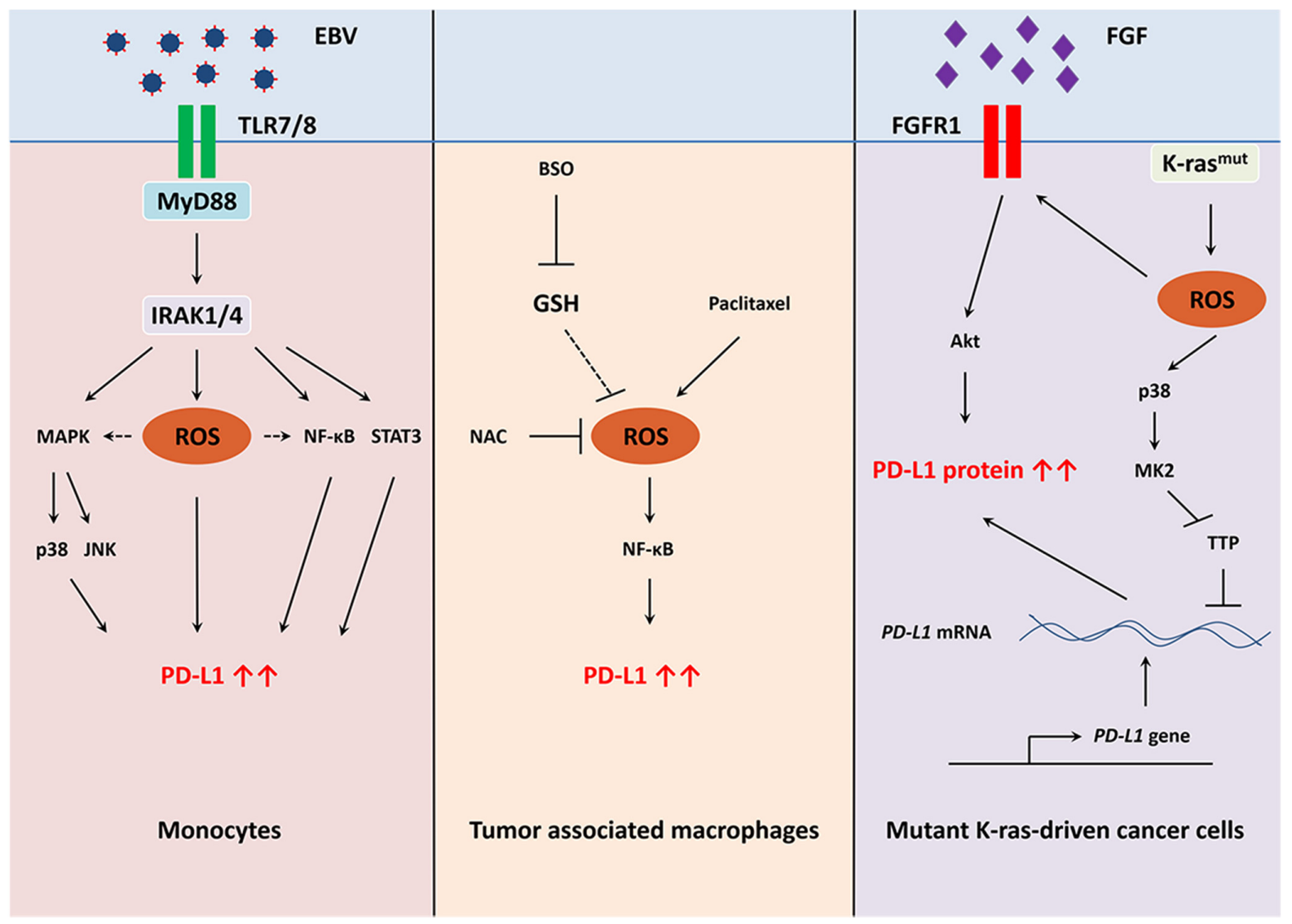

Figure 4. Redox regulation of PD-L1 in EBV-infected monocytes, tumor-associated macrophages, and mutant K-ras-driven cancer cells. ROS induce PD-L1 expression by different mechanisms in immune and cancer cells. EBV infection activates MyD88/IRAK/ROS signaling and induces PD-L1 expression in monocytes. Paclitaxel induces ROS-mediated PD-L1 upregulation in tumor associated macrophages. Mutant K-ras causes an increase in ROS production in cancer cells. This oxidative stress stimulates FGFR1 signaling and PD-L1 mRNA stability. 


\section{Conclusions}

Although PD-L1 inhibitors showed promising therapeutic effects, we raised the question of whether targeting PD-L1 by decreasing or increasing its function in tumor cells is really a good therapeutic option. On one hand, authors have tried to increase PD-L1 expression in cancer cells in order to sensitize cancer cells to PD-1/PD-L1 immune checkpoint blockade with some success in preclinical models. While these studies are important with respect to understanding the mechanisms of PD-L1 regulation and potential clinical implications, artificially inducing PD-L1 expression in cancer may not be a good therapeutic strategy. Indeed, this strategy appears to be a double-edged sword as it could potentially enhance tumor immunosuppression. Tumor tissues with high intrinsic expression of PD-L1 tend to be a reflection of adaptive resistance to initial immune attack and could be overcome by therapeutic antibodies, whereas artificial induction of PD-L1 expression would promote immunosuppression, which should be avoided. On the other hand, decreasing PD-L1 protein (i.e., metformin) levels could be an effective strategy but the use of anti-PD-1/PD-L1 antibodies could lead to similar results and might become obsolete because of the loss of immune checkpoint expression. Therefore, protocol targeting PD-L1 expression could be supplemented with other immunotherapies such as anti-CTLA-4. As explained in this review, the regulation of PD-L1 expression is very complex and controlled via multi-step levels. Selecting one of these steps to alter the immune checkpoint expression might be inefficient because the other regulatory elements might compensate and be hyperactivated. Moreover, PD-L1 surface expression on antigen-presenting cells, stromal cells, and epithelial cells also participate in immune evasion and may be regulated by different mechanisms. However, targeting the protein stability (i.e., Akt inhibitors) or PTM (i.e., monoclonal antibodies) could be a very interesting approach to inhibit the PD-1/PD-L1 interaction between all these cells in the tumor microenvironment.

In the context of clinical relevance, the information regarding the exact role of each individual oncogene on tumor immune response is currently limited and insufficient as a basis to formulate optimal immunotherapeutic strategies. Furthermore, since some tumors may have mutations in multiple genes such as K-ras and p53 in the same cells, this would make it even more complicated to formulate oncogene-specific immunotherapy. Obviously, further studies are needed in this area. However, the upregulation of PD-L1 by ROS/redox signaling and oncogenes such as K-ras is of particular significance, since ROS stress and activation of K-ras are frequently observed in various types of human cancers. Furthermore, because ROS play a major role in upregulation of PD-L1 expression, modulation of redox signaling could be a potential strategy to alter tumor immune microenvironment and improve the efficacy of immunotherapy. Such therapeutic strategy is novel and requires further evaluation in clinically relevant settings.

A combination of anti-PD-1/PD-L1 antibodies or PD-L1 degraders with chemotherapies could be the most feasible and effective manner to overcome resistance and allow a multitarget mechanism of action. However, we should be cautious about the choice of chemotherapies. These drugs should not inhibit immune cell function and have the potential to activate the immune system or induce immune cell infiltration into the tumor environment. In this context, potential immunosuppressive (arsenic trioxide, camptothecin, and fludarabine) and immunostimulant (i.e., melphalan, doxorubicin, paclitaxel, cisplatin) drugs were identified in vitro but the therapeutic effect of such immunochemotherapy regimens including these drugs still need to be investigated in preclinical and clinical studies [212]. Major efforts must be undertaken now to find the best combination therapies and understand in detail the related molecular mechanisms of action.

Author Contributions: Conceptualization, C.G.; writing-original draft preparation, C.G.; writingreview and editing, X.X. and P.H. All authors have read and agreed to the published version of the manuscript.

Funding: This research received no external funding.

Acknowledgments: The authors would like to thank Seeruttun Sharvesh Raj for language editing. 
Conflicts of Interest: The authors declare no conflict of interest.

\begin{abstract}
Abbreviations
Akt (PKB): protein kinase B; AMPK: adenosine 5'-monophosphate (AMP)-activated protein kinase; AP-1: activator protein 1; ARF6: ADP Ribosylation Factor 6; ASAP1: ArfGAP with SH3 domain, ankyrin repeat and PH domain 1; AUF1: AU-rich element binding protein 1; BET: bromo- and extraterminal domain; BIN1: bridging integrator-1; BSO: buthionine sulfoximine; CDK4: cyclin-dependent kinase 4; CMTM: chemokine-like factor-like MARVEL transmembrane domain containing family member; c-Myc: Myc proto-oncogene; CSN6: COP9 signalosome 6; DNMT: DNA methyltransferase; EBV: Epstein-Barr virus; EGFR: epidermal growth factor receptor; EML4-ALK: echinoderm microtubule associated protein like 4-anaplastic lymphoma kinase; EZH2: enhancer of zeste homolog 2; FGF(R): fibroblast growth factor (receptor); FRA1: FOS-related antigen 1; GLT1D1: glycosyltransferase 1 domain containing 1; GM-CSF: granulocyte-macrophage colony stimulating factor; GSH: reduced glutathione; GSK3: glycogen synthase kinase-3; HDAC: histone acetylases; HIF-1 $\alpha$ : hypoxiainducible factor 1 alpha; IFN: interferon; IGFBP2: insulin like growth factor binding protein 2; IL: interleukin; IRAK1/4: interleukin 1 receptor-associated kinase 1/4; Jak: Janus kinase; JNK: c-Jun $\mathrm{N}$-terminal kinase; K-ras: Kirsten ras GTPase; LSD1: lysine-specific demethylase 1; MAPK: mitogenactivated protein kinase; miR34a: micro-RNA 34a; MK2: MAPK-activated protein kinase 2; mTOR: mammalian target of rapamycin; mut: mutant; MyD88: myeloid differentiation primary response 88; NAC: $N$-acetyl cysteine; NF-kB: nuclear factor kappa-B; OXSR1: oxidative stress responsive kinase 1; p38: protein of $38 \mathrm{kDa}$; p53: protein of $53 \mathrm{kDa}$; PDGFR: platelet-derived growth factor receptor; PD-L1: programed cell death ligand 1; PI3K: phosphoinositide 3-kinase; PTEN: phosphatase and tensin homolog; ROS: reactive oxygen species; SPOP: Speckle type BTB/POZ protein; STAT: signal transducer and activator of transcription; TGF- $\beta$ : transforming growth factor beta; TGIF1: TGF- $\beta$ induced factor homeobox 1; TLR7/8: Toll-like receptor 7/8; TTP: tristetraprolin; WT: wild-type; YY1: Yin Yang 1; ZEB1: zinc finger E-box binding homeobox 1.
\end{abstract}

\title{
References
}

1. Leach, D.R.; Krummel, M.F.; Allison, J.P. Enhancement of antitumor immunity by CTLA-4 blockade. Science 1996, 271, 1734-1736. [CrossRef]

2. Ishida, Y.; Agata, Y.; Shibahara, K.; Honjo, T. Induced expression of PD-1, a novel member of the immunoglobulin gene superfamily, upon programmed cell death. EMBO J. 1992, 11, 3887-3895. [CrossRef]

3. Dong, H.; Zhu, G.; Tamada, K.; Chen, L. B7-H1, a third member of the B7 family, co-stimulates T-cell proliferation and interleukin10 secretion. Nat. Med. 1999, 5, 1365-1369. [CrossRef] [PubMed]

4. Freeman, G.J.; Long, A.J.; Iwai, Y.; Bourque, K.; Chernova, T.; Nishimura, H.; Fitz, L.J.; Malenkovich, N.; Okazaki, T.; Byrne, M.C.; et al. Engagement of the PD-1 immunoinhibitory receptor by a novel B7 family member leads to negative regulation of lymphocyte activation. J. Exp. Med. 2000, 192, 1027-1034. [CrossRef]

5. Latchman, Y.; Wood, C.R.; Chernova, T.; Chaudhary, D.; Borde, M.; Chernova, I.; Iwai, Y.; Long, A.J.; Brown, J.A.; Nunes, R.; et al. PD-L2 is a second ligand for PD-1 and inhibits T cell activation. Nat. Immunol. 2001, 2, 261-268. [CrossRef] [PubMed]

6. Larsen, T.V.; Hussmann, D.; Nielsen, A.L. PD-L1 and PD-L2 expression correlated genes in non-small-cell lung cancer. Cancer Commun. 2019, 39, 30. [CrossRef]

7. Iwai, Y.; Ishida, M.; Tanaka, Y.; Okazaki, T.; Honjo, T.; Minato, N. Involvement of PD-L1 on tumor cells in the escape from host immune system and tumor immunotherapy by PD-L1 blockade. Proc. Natl. Acad. Sci. USA 2002, 99, 12293-12297. [CrossRef] [PubMed]

8. Okazaki, T.; Honjo, T. PD-1 and PD-1 ligands: From discovery to clinical application. Int. Immunol. 2007, 19, 813-824. [CrossRef]

9. Lin, D.Y.; Tanaka, Y.; Iwasaki, M.; Gittis, A.G.; Su, H.P.; Mikami, B.; Okazaki, T.; Honjo, T.; Minato, N.; Garboczi, D.N. The PD-1/PD-L1 complex resembles the antigen-binding Fv domains of antibodies and T cell receptors. Proc. Natl. Acad. Sci. USA 2008, 105, 3011-3016. [CrossRef]

10. Collins, M.; Ling, V.; Carreno, B.M. The B7 family of immune-regulatory ligands. Genome Biol. 2005, 6, 223. [CrossRef]

11. Zak, K.M.; Grudnik, P.; Magiera, K.; Domling, A.; Dubin, G.; Holak, T.A. Structural Biology of the Immune Checkpoint Receptor PD-1 and Its Ligands PD-L1/PD-L2. Structure 2017, 25, 1163-1174. [CrossRef]

12. Keir, M.E.; Butte, M.J.; Freeman, G.J.; Sharpe, A.H. PD-1 and its ligands in tolerance and immunity. Annu. Rev. Immunol. 2008, 26, 677-704. [CrossRef]

13. Nishimura, H.; Honjo, T. PD-1: An inhibitory immunoreceptor involved in peripheral tolerance. Trends Immunol. 2001, 22, 265-268. [CrossRef] 
14. Oktay, E.; Yalcin, G.D.; Ekmekci, S.; Kahraman, D.S.; Yalcin, A.; Degirmenci, M.; Dirican, A.; Altin, Z.; Ozdemir, O.; Surmeli, Z.; et al. Programmed cell death ligand-1 expression in gastroenteropancreatic neuroendocrine tumors. J. BUON 2019, 24, 779-790.

15. Ishida, M.; Iwai, Y.; Tanaka, Y.; Okazaki, T.; Freeman, G.J.; Minato, N.; Honjo, T. Differential expression of PD-L1 and PD-L2, ligands for an inhibitory receptor PD-1, in the cells of lymphohematopoietic tissues. Immunol. Lett. 2002, 84, 57-62. [CrossRef]

16. Liang, S.C.; Latchman, Y.E.; Buhlmann, J.E.; Tomczak, M.F.; Horwitz, B.H.; Freeman, G.J.; Sharpe, A.H. Regulation of PD-1, PD-L1, and PD-L2 expression during normal and autoimmune responses. Eur. J. Immunol. 2003, 33, 2706-2716. [CrossRef]

17. Curiel, T.J.; Wei, S.; Dong, H.; Alvarez, X.; Cheng, P.; Mottram, P.; Krzysiek, R.; Knutson, K.L.; Daniel, B.; Zimmermann, M.C.; et al. Blockade of B7-H1 improves myeloid dendritic cell-mediated antitumor immunity. Nat. Med. 2003, 9, 562-567. [CrossRef] [PubMed]

18. Loke, P.; Allison, J.P. PD-L1 and PD-L2 are differentially regulated by Th1 and Th2 cells. Proc. Natl. Acad. Sci. USA 2003, 100, 5336-5341. [CrossRef] [PubMed]

19. Trabattoni, D.; Saresella, M.; Biasin, M.; Boasso, A.; Piacentini, L.; Ferrante, P.; Dong, H.; Maserati, R.; Shearer, G.M.; Chen, L.; et al. B7-H1 is up-regulated in HIV infection and is a novel surrogate marker of disease progression. Blood 2003, 101, 2514-2520. [CrossRef] [PubMed]

20. Nazareth, M.R.; Broderick, L.; Simpson-Abelson, M.R.; Kelleher, R.J., Jr.; Yokota, S.J.; Bankert, R.B. Characterization of human lung tumor-associated fibroblasts and their ability to modulate the activation of tumor-associated T cells. J. Immunol. 2007, 178, 5552-5562. [CrossRef]

21. Pinchuk, I.V.; Saada, J.I.; Beswick, E.J.; Boya, G.; Qiu, S.M.; Mifflin, R.C.; Raju, G.S.; Reyes, V.E.; Powell, D.W. PD-1 ligand expression by human colonic myofibroblasts/fibroblasts regulates CD4+ T-cell activity. Gastroenterology 2008, 135, $1228-1237$. [CrossRef]

22. Das, S.; Suarez, G.; Beswick, E.J.; Sierra, J.C.; Graham, D.Y.; Reyes, V.E. Expression of B7-H1 on gastric epithelial cells: Its potential role in regulating $\mathrm{T}$ cells during Helicobacter pylori infection. J. Immunol. 2006, 176, 3000-3009. [CrossRef]

23. Ding, H.; Wu, X.; Gao, W. PD-L1 is expressed by human renal tubular epithelial cells and suppresses T cell cytokine synthesis. Clin. Immunol. 2005, 115, 184-191. [CrossRef] [PubMed]

24. Stanciu, L.A.; Bellettato, C.M.; Laza-Stanca, V.; Coyle, A.J.; Papi, A.; Johnston, S.L. Expression of programmed death-1 ligand (PD-L) 1, PD-L2, B7-H3, and inducible costimulator ligand on human respiratory tract epithelial cells and regulation by respiratory syncytial virus and type 1 and 2 cytokines. J. Infect. Dis. 2006, 193, 404-412. [CrossRef] [PubMed]

25. Reynoso, E.D.; Lee, J.W.; Turley, S.J. Peripheral tolerance induction by lymph node stroma. Adv. Exp. Med. Biol. 2009, 633, 113-127. [PubMed]

26. Kitano, Y.; Yamashita, Y.I.; Nakao, Y.; Itoyama, R.; Yusa, T.; Umezaki, N.; Tsukamoto, M.; Yamao, T.; Miyata, T.; Nakagawa, S.; et al. Clinical Significance of PD-L1 Expression in Both Cancer and Stroma Cells of Cholangiocarcinoma Patients. Ann. Surg. Oncol. 2019, 27, 599-607. [CrossRef] [PubMed]

27. Teramoto, K.; Igarashi, T.; Kataoka, Y.; Ishida, M.; Hanaoka, J.; Sumimoto, H.; Daigo, Y. Clinical significance of PD-L1-positive cancer-associated fibroblasts in pN0M0 non-small cell lung cancer. Lung Cancer 2019, 137, 56-63. [CrossRef]

28. Van Berckelaer, C.; Rypens, C.; van Dam, P.; Pouillon, L.; Parizel, M.; Schats, K.A.; Kockx, M.; Tjalma, W.A.A.; Vermeulen, P.; van Laere, S.; et al. Infiltrating stromal immune cells in inflammatory breast cancer are associated with an improved outcome and increased PD-L1 expression. Breast Cancer Res. 2019, 21, 28. [CrossRef]

29. Wyss, J.; Dislich, B.; Koelzer, V.H.; Galvan, J.A.; Dawson, H.; Hadrich, M.; Inderbitzin, D.; Lugli, A.; Zlobec, I.; Berger, M.D. Stromal PD-1/PD-L1 Expression Predicts Outcome in Colon Cancer Patients. Clin. Colorectal Cancer 2019, 18, e20-e38. [CrossRef]

30. Satelli, A.; Batth, I.S.; Brownlee, Z.; Rojas, C.; Meng, Q.H.; Kopetz, S.; Li, S. Potential role of nuclear PD-L1 expression in cell-surface vimentin positive circulating tumor cells as a prognostic marker in cancer patients. Sci. Rep. 2016, 6, 28910. [CrossRef]

31. Chowdhury, S.; Veyhl, J.; Jessa, F.; Polyakova, O.; Alenzi, A.; MacMillan, C.; Ralhan, R.; Walfish, P.G. Programmed death-ligand 1 overexpression is a prognostic marker for aggressive papillary thyroid cancer and its variants. Oncotarget 2016, 7, 32318-32328. [CrossRef]

32. Chen, L.; Deng, H.; Lu, M.; Xu, B.; Wang, Q.; Jiang, J.; Wu, C. B7-H1 expression associates with tumor invasion and predicts patient's survival in human esophageal cancer. Int. J. Clin. Exp. Pathol. 2014, 7, 6015-6023. [PubMed]

33. Ghebeh, H.; Lehe, C.; Barhoush, E.; Al-Romaih, K.; Tulbah, A.; Al-Alwan, M.; Hendrayani, S.F.; Manogaran, P.; Alaiya, A.; Al-Tweigeri, T.; et al. Doxorubicin downregulates cell surface B7-H1 expression and upregulates its nuclear expression in breast cancer cells: Role of B7-H1 as an anti-apoptotic molecule. Breast Cancer Res. 2010, 12, R48. [CrossRef]

34. He, X.H.; Xu, L.H.; Liu, Y. Identification of a novel splice variant of human PD-L1 mRNA encoding an isoform-lacking Igv-like domain. Acta Pharmacol. Sin. 2005, 26, 462-468. [CrossRef]

35. Polioudaki, H.; Chantziou, A.; Kalyvianaki, K.; Malamos, P.; Notas, G.; Mavroudis, D.; Kampa, M.; Castanas, E.; Theodoropoulos, P.A. Nuclear localization of PD-L1: Artifact or reality? Cell. Oncol. 2019, 42, 237-242. [CrossRef]

36. Latchman, Y.E.; Liang, S.C.; Wu, Y.; Chernova, T.; Sobel, R.A.; Klemm, M.; Kuchroo, V.K.; Freeman, G.J.; Sharpe, A.H. PD-L1deficient mice show that PD-L1 on T cells, antigen-presenting cells, and host tissues negatively regulates T cells. Proc. Natl. Acad. Sci. USA 2004, 101, 10691-10696. [CrossRef] [PubMed]

37. Brown, J.A.; Dorfman, D.M.; Ma, F.R.; Sullivan, E.L.; Munoz, O.; Wood, C.R.; Greenfield, E.A.; Freeman, G.J. Blockade of programmed death-1 ligands on dendritic cells enhances T cell activation and cytokine production. J. Immunol. 2003, 170, 1257-1266. [CrossRef] 
38. Mazanet, M.M.; Hughes, C.C. B7-H1 is expressed by human endothelial cells and suppresses T cell cytokine synthesis. J. Immunol. 2002, 169, 3581-3588. [CrossRef] [PubMed]

39. Rodig, N.; Ryan, T.; Allen, J.A.; Pang, H.; Grabie, N.; Chernova, T.; Greenfield, E.A.; Liang, S.C.; Sharpe, A.H.; Lichtman, A.H.; et al. Endothelial expression of PD-L1 and PD-L2 down-regulates CD8+ T cell activation and cytolysis. Eur. J. Immunol. 2003, 33, 3117-3126. [CrossRef] [PubMed]

40. Wintterle, S.; Schreiner, B.; Mitsdoerffer, M.; Schneider, D.; Chen, L.; Meyermann, R.; Weller, M.; Wiendl, H. Expression of the B7-related molecule B7-H1 by glioma cells: A potential mechanism of immune paralysis. Cancer Res. 2003, 63, 7462-7467.

41. Nishimura, H.; Nose, M.; Hiai, H.; Minato, N.; Honjo, T. Development of lupus-like autoimmune diseases by disruption of the PD-1 gene encoding an ITIM motif-carrying immunoreceptor. Immunity 1999, 11, 141-151. [CrossRef]

42. Nishimura, H.; Okazaki, T.; Tanaka, Y.; Nakatani, K.; Hara, M.; Matsumori, A.; Sasayama, S.; Mizoguchi, A.; Hiai, H.; Minato, N.; et al. Autoimmune dilated cardiomyopathy in PD-1 receptor-deficient mice. Science 2001, 291, 319-322. [CrossRef] [PubMed]

43. Wang, J.; Yoshida, T.; Nakaki, F.; Hiai, H.; Okazaki, T.; Honjo, T. Establishment of NOD-Pdcd1-/- mice as an efficient animal model of type I diabetes. Proc. Natl. Acad. Sci. USA 2005, 102, 11823-11828. [CrossRef]

44. Lau, J.; Cheung, J.; Navarro, A.; Lianoglou, S.; Haley, B.; Totpal, K.; Sanders, L.; Koeppen, H.; Caplazi, P.; McBride, J.; et al. Tumour and host cell PD-L1 is required to mediate suppression of anti-tumour immunity in mice. Nat. Commun. 2017, 8, 14572. [CrossRef]

45. Blank, C.; Gajewski, T.F.; Mackensen, A. Interaction of PD-L1 on tumor cells with PD-1 on tumor-specific T cells as a mechanism of immune evasion: Implications for tumor immunotherapy. Cancer Immunol. Immunother. 2005, 54, 307-314. [CrossRef]

46. Mortezaee, K. Immune escape: A critical hallmark in solid tumors. Life Sci. 2020, 258, 118110. [CrossRef]

47. Hamid, O.; Carvajal, R.D. Anti-programmed death-1 and anti-programmed death-ligand 1 antibodies in cancer therapy. Expert Opin. Biol. Ther. 2013, 13, 847-861. [CrossRef]

48. Wang, X.; Teng, F.; Kong, L.; Yu, J. PD-L1 expression in human cancers and its association with clinical outcomes. Onco Targets Ther. 2016, 9, 5023-5039. [PubMed]

49. Brahmer, J.; Reckamp, K.L.; Baas, P.; Crino, L.; Eberhardt, W.E.; Poddubskaya, E.; Antonia, S.; Pluzanski, A.; Vokes, E.E.; Holgado, E.; et al. Nivolumab versus Docetaxel in Advanced Squamous-Cell Non-Small-Cell Lung Cancer. N. Engl. J. Med. 2015, 373, 123-135. [CrossRef] [PubMed]

50. Carbone, D.P.; Reck, M.; Paz-Ares, L.; Creelan, B.; Horn, L.; Steins, M.; Felip, E.; van den Heuvel, M.M.; Ciuleanu, T.E.; Badin, F.; et al. First-Line Nivolumab in Stage IV or Recurrent Non-Small-Cell Lung Cancer. N. Engl. J. Med. 2017, 376, 2415-2426. [CrossRef] [PubMed]

51. Hanna, G.J.; Lizotte, P.; Cavanaugh, M.; Kuo, F.C.; Shivdasani, P.; Frieden, A.; Chau, N.G.; Schoenfeld, J.D.; Lorch, J.H.; Uppaluri, R.; et al. Frameshift events predict anti-PD-1/L1 response in head and neck cancer. JCI Insight 2018, 3, e98811. [CrossRef]

52. Jerby-Arnon, L.; Shah, P.; Cuoco, M.S.; Rodman, C.; Su, M.J.; Melms, J.C.; Leeson, R.; Kanodia, A.; Mei, S.; Lin, J.R.; et al. A Cancer Cell Program Promotes T Cell Exclusion and Resistance to Checkpoint Blockade. Cell 2018, 175, 984-997. [CrossRef] [PubMed]

53. Weber, J. Immunotherapy for melanoma. Curr. Opin. Oncol. 2011, 23, 163-169. [CrossRef]

54. Henriksen, A.; Dyhl-Polk, A.; Chen, I.; Nielsen, D. Checkpoint inhibitors in pancreatic cancer. Cancer Treat Rev. 2019, 78, 17-30. [CrossRef] [PubMed]

55. Mehrvarz Sarshekeh, A.; Overman, M.J.; Kopetz, S. Nivolumab in the treatment of microsatellite instability high metastatic colorectal cancer. Future Oncol. 2018, 14, 1869-1874. [CrossRef] [PubMed]

56. Wang, Z.; Wu, X. Study and analysis of antitumor resistance mechanism of PD1/PD-L1 immune checkpoint blocker. Cancer Med. 2020, 9, 8086-8121. [CrossRef]

57. Lacour, M.; Hiltbrunner, S.; Lee, S.Y.; Soltermann, A.; Rushing, E.J.; Soldini, D.; Weder, W.; Curioni-Fontecedro, A. Adjuvant Chemotherapy Increases Programmed Death-Ligand 1 (PD-L1) Expression in Non-small Cell Lung Cancer Recurrence. Clin. Lung Cancer 2019, 20, 391-396. [CrossRef]

58. Liu, Y.T.; Sun, Z.J. Turning cold tumors into hot tumors by improving T-cell infiltration. Theranostics 2021, 11, 5365-5386. [CrossRef]

59. Fabrizio, F.P.; Trombetta, D.; Rossi, A.; Sparaneo, A.; Castellana, S.; Muscarella, L.A. Gene code CD274/PD-L1: From molecular basis toward cancer immunotherapy. Ther. Adv. Med. Oncol. 2018, 10, 1758835918815598. [CrossRef]

60. Liu, H.; Zhang, B.; Sun, Z. Spectrum of EGFR aberrations and potential clinical implications: Insights from integrative pan-cancer analysis. Cancer Commun. 2020, 40, 43-59. [CrossRef] [PubMed]

61. Green, M.R.; Monti, S.; Rodig, S.J.; Juszczynski, P.; Currie, T.; O’Donnell, E.; Chapuy, B.; Takeyama, K.; Neuberg, D.; Golub, T.R.; et al. Integrative analysis reveals selective 9p24.1 amplification, increased PD-1 ligand expression, and further induction via JAK2 in nodular sclerosing Hodgkin lymphoma and primary mediastinal large B-cell lymphoma. Blood 2010, 116, $3268-3277$. [CrossRef]

62. Roemer, M.G.; Advani, R.H.; Ligon, A.H.; Natkunam, Y.; Redd, R.A.; Homer, H.; Connelly, C.F.; Sun, H.H.; Daadi, S.E.; Freeman, G.J.; et al. PD-L1 and PD-L2 Genetic Alterations Define Classical Hodgkin Lymphoma and Predict Outcome. J. Clin. Oncol. 2016, 34, 2690-2697. [CrossRef]

63. Barrett, M.T.; Anderson, K.S.; Lenkiewicz, E.; Andreozzi, M.; Cunliffe, H.E.; Klassen, C.L.; Dueck, A.C.; McCullough, A.E.; Reddy, S.K.; Ramanathan, R.K.; et al. Genomic amplification of 9p24.1 targeting JAK2, PD-L1, and PD-L2 is enriched in high-risk triple negative breast cancer. Oncotarget 2015, 6, 26483-26493. [CrossRef] 
64. Chen, M.; Andreozzi, M.; Pockaj, B.; Barrett, M.T.; Ocal, I.T.; McCullough, A.E.; Linnaus, M.E.; Chang, J.M.; Yearley, J.H.; Annamalai, L.; et al. Development and validation of a novel clinical fluorescence in situ hybridization assay to detect JAK2 and PD-L1 amplification: A fluorescence in situ hybridization assay for JAK2 and PD-L1 amplification. Mod. Pathol. 2017, 30, 1516-1526. [CrossRef]

65. George, J.; Saito, M.; Tsuta, K.; Iwakawa, R.; Shiraishi, K.; Scheel, A.H.; Uchida, S.; Watanabe, S.I.; Nishikawa, R.; Noguchi, M.; et al. Genomic Amplification of CD274 (PD-L1) in Small-Cell Lung Cancer. Clin. Cancer Res. 2017, 23, 1220-1226. [CrossRef]

66. Lamberti, G.; Spurr, L.F.; Li, Y.; Ricciuti, B.; Recondo, G.; Umeton, R.; Nishino, M.; Sholl, L.M.; Meyerson, M.L.; Cherniack, A.D.; et al. Clinicopathological and genomic correlates of programmed cell death ligand 1 (PD-L1) expression in nonsquamous non-small-cell lung cancer. Ann. Oncol. 2020, 31, 807-814. [CrossRef]

67. Kula, A.; Dawidowicz, M.; Kiczmer, P.; Prawdzic Senkowska, A.; Swietochowska, E. The role of genetic polymorphism within PD-L1 gene in cancer. Review. Exp. Mol. Pathol. 2020, 116, 104494. [CrossRef]

68. Kumar, S.; Sharawat, S.K. Epigenetic regulators of programmed death-ligand 1 expression in human cancers. Transl. Res. 2018, 202, 129-145. [CrossRef]

69. Wang, Y.; Wang, H.; Yao, H.; Li, C.; Fang, J.Y.; Xu, J. Regulation of PD-L1: Emerging Routes for Targeting Tumor Immune Evasion. Front. Pharmacol. 2018, 9, 536. [CrossRef]

70. Gevensleben, H.; Holmes, E.E.; Goltz, D.; Dietrich, J.; Sailer, V.; Ellinger, J.; Dietrich, D.; Kristiansen, G. PD-L1 promoter methylation is a prognostic biomarker for biochemical recurrence-free survival in prostate cancer patients following radical prostatectomy. Oncotarget 2016, 7, 79943-79955. [CrossRef]

71. Chatterjee, A.; Rodger, E.J.; Ahn, A.; Stockwell, P.A.; Parry, M.; Motwani, J.; Gallagher, S.J.; Shklovskaya, E.; Tiffen, J.; Eccles, M.R.; et al. Marked Global DNA Hypomethylation Is Associated with Constitutive PD-L1 Expression in Melanoma. Iscience 2018, 4, 312-325. [CrossRef]

72. Micevic, G.; Thakral, D.; McGeary, M.; Bosenberg, M.W. PD-L1 methylation regulates PD-L1 expression and is associated with melanoma survival. Pigment. Cell Melanoma Res. 2019, 32, 435-440. [CrossRef]

73. Elashi, A.A.; Sasidharan Nair, V.; Taha, R.Z.; Shaath, H.; Elkord, E. DNA methylation of immune checkpoints in the peripheral blood of breast and colorectal cancer patients. Oncoimmunology 2019, 8, e1542918. [CrossRef] [PubMed]

74. Sasidharan Nair, V.; Toor, S.M.; Taha, R.Z.; Shaath, H.; Elkord, E. DNA methylation and repressive histones in the promoters of PD-1, CTLA-4, TIM-3, LAG-3, TIGIT, PD-L1, and galectin-9 genes in human colorectal cancer. Clin. Epigenetics 2018, 10, 104. [CrossRef]

75. Emran, A.A.; Chatterjee, A.; Rodger, E.J.; Tiffen, J.C.; Gallagher, S.J.; Eccles, M.R.; Hersey, P. Targeting DNA Methylation and EZH2 Activity to Overcome Melanoma Resistance to Immunotherapy. Trends Immunol. 2019, 40, 328-344. [CrossRef]

76. Li, X.; Wang, Z.; Huang, J.; Luo, H.; Zhu, S.; Yi, H.; Zheng, L.; Hu, B.; Yu, L.; Li, L.; et al. Specific zinc finger-induced methylation of PD-L1 promoter inhibits its expression. FEBS Open Bio 2019, 9, 1063-1070. [CrossRef] [PubMed]

77. De Beck, L.; Melhaoui, S.; De Veirman, K.; Menu, E.; De Bruyne, E.; Vanderkerken, K.; Breckpot, K.; Maes, K. Epigenetic treatment of multiple myeloma mediates tumor intrinsic and extrinsic immunomodulatory effects. Oncoimmunology 2018, 7, e1484981. [CrossRef] [PubMed]

78. Xiao, G.; Jin, L.L.; Liu, C.Q.; Wang, Y.C.; Meng, Y.M.; Zhou, Z.G.; Chen, J.; Yu, X.J.; Zhang, Y.J.; Xu, J.; et al. EZH2 negatively regulates PD-L1 expression in hepatocellular carcinoma. J. Immunother. Cancer 2019, 7, 300. [CrossRef] [PubMed]

79. Zhao, Y.; Wang, X.X.; Wu, W.; Long, H.; Huang, J.; Wang, Z.; Li, T.; Tang, S.; Zhu, B.; Chen, D. EZH2 regulates PD-L1 expression via HIF-1alpha in non-small cell lung cancer cells. Biochem. Biophys. Res. Commun. 2019, 517, 201-209. [CrossRef]

80. Mao, W.; Ghasemzadeh, A.; Freeman, Z.T.; Obradovic, A.; Chaimowitz, M.G.; Nirschl, T.R.; McKiernan, E.; Yegnasubramanian, S.; Drake, C.G. Immunogenicity of prostate cancer is augmented by BET bromodomain inhibition. J. Immunother. Cancer $2019,7,277$. [CrossRef]

81. Li, N.; Yang, L.; Qi, X.K.; Lin, Y.X.; Xie, X.; He, G.P.; Feng, Q.S.; Liu, L.R.; Xie, X.; Zeng, Y.X.; et al. BET bromodomain inhibitor JQ1 preferentially suppresses EBV-positive nasopharyngeal carcinoma cells partially through repressing c-Myc. Cell Death Dis. 2018, 9, 761. [CrossRef] [PubMed]

82. Wang, W.; Tan, J. Co-inhibition of BET proteins and PD-L1 as a potential therapy for OSCC through synergistic inhibition of FOXM1 and PD-L1 expressions. J. Oral. Pathol. Med. 2019, 48, 817-825. [CrossRef] [PubMed]

83. Erkes, D.A.; Field, C.O.; Capparelli, C.; Tiago, M.; Purwin, T.J.; Chervoneva, I.; Berger, A.C.; Hartsough, E.J.; Villanueva, J.; Aplin, A.E. The next-generation BET inhibitor, PLX51107, delays melanoma growth in a CD8-mediated manner. Pigment Cell Melanoma Res. 2019, 32, 687-696. [CrossRef] [PubMed]

84. Ebine, K.; Kumar, K.; Pham, T.N.; Shields, M.A.; Collier, K.A.; Shang, M.; DeCant, B.T.; Urrutia, R.; Hwang, R.F.; Grimaldo, S.; et al. Interplay between interferon regulatory factor 1 and BRD4 in the regulation of PD-L1 in pancreatic stellate cells. Sci. Rep. 2018, 8, 13225. [CrossRef] [PubMed]

85. Deng, S.; Hu, Q.; Zhang, H.; Yang, F.; Peng, C.; Huang, C. HDAC3 Inhibition Upregulates PD-L1 Expression in B-Cell Lymphomas and Augments the Efficacy of Anti-PD-L1 Therapy. Mol. Cancer Ther. 2019, 18, 900-908. [CrossRef]

86. Hicks, K.C.; Fantini, M.; Donahue, R.N.; Schwab, A.; Knudson, K.M.; Tritsch, S.R.; Jochems, C.; Clavijo, P.E.; Allen, C.T.; Hodge, J.W.; et al. Epigenetic priming of both tumor and NK cells augments antibody-dependent cellular cytotoxicity elicited by the anti-PD-L1 antibody avelumab against multiple carcinoma cell types. Oncoimmunology 2018, 7, e1466018. [CrossRef] 
87. Li, T.; Zhang, C.; Hassan, S.; Liu, X.; Song, F.; Chen, K.; Zhang, W.; Yang, J. Histone deacetylase 6 in cancer. J. Hematol. Oncol. 2018, 11, 111. [CrossRef] [PubMed]

88. Fukumoto, T.; Fatkhutdinov, N.; Zundell, J.A.; Tcyganov, E.N.; Nacarelli, T.; Karakashev, S.; Wu, S.; Liu, Q.; Gabrilovich, D.I.; Zhang, R. HDAC6 Inhibition Synergizes with Anti-PD-L1 Therapy in ARID1A-Inactivated Ovarian Cancer. Cancer Res. 2019, 79, 5482-5489. [CrossRef]

89. Qin, Y.; Vasilatos, S.N.; Chen, L.; Wu, H.; Cao, Z.; Fu, Y.; Huang, M.; Vlad, A.M.; Lu, B.; Oesterreich, S.; et al. Inhibition of histone lysine-specific demethylase 1 elicits breast tumor immunity and enhances antitumor efficacy of immune checkpoint blockade. Oncogene 2019, 38, 390-405. [CrossRef] [PubMed]

90. Parsa, A.T.; Waldron, J.S.; Panner, A.; Crane, C.A.; Parney, I.F.; Barry, J.J.; Cachola, K.E.; Murray, J.C.; Tihan, T.; Jensen, M.C.; et al. Loss of tumor suppressor PTEN function increases B7-H1 expression and immunoresistance in glioma. Nat. Med. 2007, 13, 84-88. [CrossRef] [PubMed]

91. Cretella, D.; Digiacomo, G.; Giovannetti, E.; Cavazzoni, A. PTEN Alterations as a Potential Mechanism for Tumor Cell Escape from PD-1/PD-L1 Inhibition. Cancers 2019, 11, 1318. [CrossRef]

92. Xu, C.; Fillmore, C.M.; Koyama, S.; Wu, H.; Zhao, Y.; Chen, Z.; Herter-Sprie, G.S.; Akbay, E.A.; Tchaicha, J.H.; Altabef, A.; et al. Loss of Lkb1 and Pten leads to lung squamous cell carcinoma with elevated PD-L1 expression. Cancer Cell 2014, 25, 590-604. [CrossRef] [PubMed]

93. Chen, N.; Fang, W.; Zhan, J.; Hong, S.; Tang, Y.; Kang, S.; Zhang, Y.; He, X.; Zhou, T.; Qin, T.; et al. Upregulation of PD-L1 by EGFR Activation Mediates the Immune Escape in EGFR-Driven NSCLC: Implication for Optional Immune Targeted Therapy for NSCLC Patients with EGFR Mutation. J. Thorac. Oncol. 2015, 10, 910-923. [CrossRef] [PubMed]

94. Jiang, X.; Zhou, J.; Giobbie-Hurder, A.; Wargo, J.; Hodi, F.S. The activation of MAPK in melanoma cells resistant to BRAF inhibition promotes PD-L1 expression that is reversible by MEK and PI3K inhibition. Clin. Cancer Res. 2013, 19, 598-609. [CrossRef] [PubMed]

95. Cha, J.H.; Yang, W.H.; Xia, W.; Wei, Y.; Chan, L.C.; Lim, S.O.; Li, C.W.; Kim, T.; Chang, S.S.; Lee, H.H.; et al. Metformin Promotes Antitumor Immunity via Endoplasmic-Reticulum-Associated Degradation of PD-L1. Mol. Cell 2018, 71, 606-620. [CrossRef]

96. Bellucci, R.; Martin, A.; Bommarito, D.; Wang, K.; Hansen, S.H.; Freeman, G.J.; Ritz, J. Interferon-gamma-induced activation of JAK1 and JAK2 suppresses tumor cell susceptibility to NK cells through upregulation of PD-L1 expression. Oncoimmunology 2015, 4, e1008824. [CrossRef] [PubMed]

97. Wolfle, S.J.; Strebovsky, J.; Bartz, H.; Sahr, A.; Arnold, C.; Kaiser, C.; Dalpke, A.H.; Heeg, K. PD-L1 expression on tolerogenic APCs is controlled by STAT-3. Eur. J. Immunol. 2011, 41, 413-424. [CrossRef]

98. Tuo, Z.; Zong, Y.; Li, J.; Xiao, G.; Zhang, F.; Li, G.; Wang, S.; Lv, Y.; Xia, J.; Liu, J. PD-L1 regulation by SDH5 via beta-catenin/ZEB1 signaling. Oncoimmunology 2019, 8, 1655361. [CrossRef] [PubMed]

99. Huang, G.; Wen, Q.; Zhao, Y.; Gao, Q.; Bai, Y. NF-kappaB plays a key role in inducing CD274 expression in human monocytes after lipopolysaccharide treatment. PLoS ONE 2013, 8, e61602.

100. Kondo, A.; Yamashita, T.; Tamura, H.; Zhao, W.; Tsuji, T.; Shimizu, M.; Shinya, E.; Takahashi, H.; Tamada, K.; Chen, L.; et al. Interferon-gamma and tumor necrosis factor-alpha induce an immunoinhibitory molecule, B7-H1, via nuclear factor-kappaB activation in blasts in myelodysplastic syndromes. Blood 2010, 116, 1124-1131. [CrossRef]

101. Jabbarzadeh Kaboli, P.; Salimian, F.; Aghapour, S.; Xiang, S.; Zhao, Q.; Li, M.; Wu, X.; Du, F.; Zhao, Y.; Shen, J.; et al. Akt-targeted therapy as a promising strategy to overcome drug resistance in breast cancer-A comprehensive review from chemotherapy to immunotherapy. Pharmacol. Res. 2020, 156, 104806. [CrossRef] [PubMed]

102. Casey, S.C.; Tong, L.; Li, Y.; Do, R.; Walz, S.; Fitzgerald, K.N.; Gouw, A.M.; Baylot, V.; Gutgemann, I.; Eilers, M.; et al. MYC regulates the antitumor immune response through CD47 and PD-L1. Science 2016, 352, 227-231. [CrossRef] [PubMed]

103. Marzec, M.; Zhang, Q.; Goradia, A.; Raghunath, P.N.; Liu, X.; Paessler, M.; Wang, H.Y.; Wysocka, M.; Cheng, M.; Ruggeri, B.A.; et al. Oncogenic kinase NPM/ALK induces through STAT3 expression of immunosuppressive protein CD274 (PD-L1, B7-H1). Proc. Natl. Acad. Sci. USA 2008, 105, 20852-20857. [CrossRef] [PubMed]

104. Hays, E.; Bonavida, B. YY1 regulates cancer cell immune resistance by modulating PD-L1 expression. Drug Resist. Updates 2019, 43, 10-28. [CrossRef] [PubMed]

105. Fang, W.; Zhang, J.; Hong, S.; Zhan, J.; Chen, N.; Qin, T.; Tang, Y.; Zhang, Y.; Kang, S.; Zhou, T.; et al. EBV-driven LMP1 and IFN-gamma up-regulate PD-L1 in nasopharyngeal carcinoma: Implications for oncotargeted therapy. Oncotarget 2014, 5, 12189-12202. [CrossRef]

106. Green, M.R.; Rodig, S.; Juszczynski, P.; Ouyang, J.; Sinha, P.; O’Donnell, E.; Neuberg, D.; Shipp, M.A. Constitutive AP-1 activity and EBV infection induce PD-L1 in Hodgkin lymphomas and posttransplant lymphoproliferative disorders: Implications for targeted therapy. Clin. Cancer Res. 2012, 18, 1611-1618. [CrossRef]

107. Labiano, S.; Palazon, A.; Melero, I. Immune response regulation in the tumor microenvironment by hypoxia. Semin. Oncol. 2015, 42, 378-386. [CrossRef]

108. Noman, M.Z.; Desantis, G.; Janji, B.; Hasmim, M.; Karray, S.; Dessen, P.; Bronte, V.; Chouaib, S. PD-L1 is a novel direct target of HIF-1alpha, and its blockade under hypoxia enhanced MDSC-mediated T cell activation. J. Exp. Med. 2014, 211, 781-790. [CrossRef]

109. Xu, Y.; Wu, Y.; Zhang, S.; Ma, P.; Jin, X.; Wang, Z.; Yao, M.; Zhang, E.; Tao, B.; Qin, Y.; et al. A Tumor-Specific Super-Enhancer Drives Immune Evasion by Guiding Synchronous Expression of PD-L1 and PD-L2. Cell Rep. 2019, 29, 3435-3447. [CrossRef] 
110. Kim, D.J.; Jang, J.H.; Ham, S.Y.; Choi, S.H.; Park, S.S.; Jeong, S.Y.; Kim, B.C.; Jeon, D.Y.; Lee, B.J.; Ko, B.K.; et al. Doxorubicin inhibits PD-L1 expression by enhancing TTP-mediated decay of PD-L1 mRNA in cancer cells. Biochem. Biophys. Res. Commun. 2020, 522, 402-407. [CrossRef]

111. Wang, T.; Chen, S.; Wang, X.; Huang, Y.; Qiu, J.; Fei, Y.; Chaulagain, A.; Chen, Y.; Wang, Y.; Lin, L.; et al. Aberrant PD-1 ligand expression contributes to the myocardial inflammatory injury caused by Coxsackievirus B infection. Antiviral Res. 2019, 166, 1-10. [CrossRef] [PubMed]

112. Omar, H.A.; El-Serafi, A.T.; Hersi, F.; Arafa, E.A.; Zaher, D.M.; Madkour, M.; Arab, H.H.; Tolba, M.F. Immunomodulatory MicroRNAs in cancer: Targeting immune checkpoints and the tumor microenvironment. FEBS J. 2019, 286, 3540-3557. [CrossRef] [PubMed]

113. Li, C.W.; Lim, S.O.; Xia, W.; Lee, H.H.; Chan, L.C.; Kuo, C.W.; Khoo, K.H.; Chang, S.S.; Cha, J.H.; Kim, T.; et al. Glycosylation and stabilization of programmed death ligand-1 suppresses T-cell activity. Nat. Commun. 2016, 7, 12632. [CrossRef] [PubMed]

114. Li, C.W.; Lim, S.O.; Chung, E.M.; Kim, Y.S.; Park, A.H.; Yao, J.; Cha, J.H.; Xia, W.; Chan, L.C.; Kim, T.; et al. Eradication of Triple-Negative Breast Cancer Cells by Targeting Glycosylated PD-L1. Cancer Cell 2018, 33, 187-201. [CrossRef]

115. Liu, X.; Zhang, Y.; Han, Y.; Lu, W.; Yang, J.; Tian, J.; Sun, P.; Yu, T.; Hu, Y.; Zhang, H.; et al. Overexpression of GLT1D1 induces immunosuppression through glycosylation of PD-L1 and predicts poor prognosis in B-cell lymphoma. Mol. Oncol. 2020, 14, 1028-1044. [CrossRef]

116. Cha, J.H.; Chan, L.C.; Li, C.W.; Hsu, J.L.; Hung, M.C. Mechanisms Controlling PD-L1 Expression in Cancer. Mol. Cell 2019, 76, 359-370. [CrossRef]

117. Mezzadra, R.; Sun, C.; Jae, L.T.; Gomez-Eerland, R.; de Vries, E.; Wu, W.; Logtenberg, M.E.W.; Slagter, M.; Rozeman, E.A.; Hofland, I.; et al. Identification of CMTM6 and CMTM4 as PD-L1 protein regulators. Nature 2017, 549, 106-110. [CrossRef]

118. Zhang, J.; Bu, X.; Wang, H.; Zhu, Y.; Geng, Y.; Nihira, N.T.; Tan, Y.; Ci, Y.; Wu, F.; Dai, X.; et al. Cyclin D-CDK4 kinase destabilizes PD-L1 via cullin 3-SPOP to control cancer immune surveillance. Nature 2018, 553, 91-95. [CrossRef]

119. Yang, L.; Huang, F.; Mei, J.; Wang, X.; Zhang, Q.; Wang, H.; Xi, M.; You, Z. Posttranscriptional Control of PD-L1 Expression by 17beta-Estradiol via PI3K/Akt Signaling Pathway in ERalpha-Positive Cancer Cell Lines. Int. J. Gynecol. Cancer 2017, $27,196-205$. [CrossRef]

120. Dreher, L.S.; Hoppe, T. ERADicate Tumor Progression with Metformin. Mol. Cell 2018, 71, 481-482. [CrossRef]

121. Gong, A.Y.; Zhou, R.; Hu, G.; Li, X.; Splinter, P.L.; O’Hara, S.P.; LaRusso, N.F.; Soukup, G.A.; Dong, H.; Chen, X.M. MicroRNA-513 regulates B7-H1 translation and is involved in IFN-gamma-induced B7-H1 expression in cholangiocytes. J. Immunol. 2009, 182, 1325-1333. [CrossRef]

122. Liu, J.; Hamrouni, A.; Wolowiec, D.; Coiteux, V.; Kuliczkowski, K.; Hetuin, D.; Saudemont, A.; Quesnel, B. Plasma cells from multiple myeloma patients express B7-H1 (PD-L1) and increase expression after stimulation with IFN-\{gamma\} and TLR ligands via a MyD88-, TRAF6-, and MEK-dependent pathway. Blood 2007, 110, 296-304. [CrossRef] [PubMed]

123. Xiao, W.; Klement, J.D.; Lu, C.; Ibrahim, M.L.; Liu, K. IFNAR1 Controls Autocrine Type I IFN Regulation of PD-L1 Expression in Myeloid-Derived Suppressor Cells. J. Immunol. 2018, 201, 264-277. [CrossRef] [PubMed]

124. Song, S.; Yuan, P.; Wu, H.; Chen, J.; Fu, J.; Li, P.; Lu, J.; Wei, W. Dendritic cells with an increased PD-L1 by TGF-beta induce T cell anergy for the cytotoxicity of hepatocellular carcinoma cells. Int. Immunopharmacol. 2014, 20, 117-123. [CrossRef] [PubMed]

125. Tamura, H.; Ishibashi, M.; Yamashita, T.; Tanosaki, S.; Okuyama, N.; Kondo, A.; Hyodo, H.; Shinya, E.; Takahashi, H.; Dong, H.; et al. Marrow stromal cells induce B7-H1 expression on myeloma cells, generating aggressive characteristics in multiple myeloma. Leukemia 2013, 27, 464-472. [CrossRef] [PubMed]

126. Yang, M.; Liu, P.; Wang, K.; Glorieux, C.; Hu, Y.; Wen, S.; Jiang, W.; Huang, P. Chemotherapy induces tumor immune evasion by upregulation of programmed cell death ligand 1 expression in bone marrow stromal cells. Mol. Oncol. 2017, 11, 358-372. [CrossRef]

127. Spranger, S.; Gajewski, T.F. Impact of oncogenic pathways on evasion of antitumour immune responses. Nat. Rev. Cancer 2018, 18, 139-147. [CrossRef]

128. McNiel, E.A.; Tsichlis, P.N. Analyses of publicly available genomics resources define FGF-2-expressing bladder carcinomas as EMT-prone, proliferative tumors with low mutation rates and high expression of CTLA-4, PD-1 and PD-L1. Signal Transduct. Target. Ther. 2017, 2, 16045. [CrossRef]

129. Li, P.; Huang, T.; Zou, Q.; Liu, D.; Wang, Y.; Tan, X.; Wei, Y.; Qiu, H. FGFR2 Promotes Expression of PD-L1 in Colorectal Cancer via the JAK/STAT3 Signaling Pathway. J. Immunol. 2019, 202, 3065-3075. [CrossRef]

130. Palakurthi, S.; Kuraguchi, M.; Zacharek, S.J.; Zudaire, E.; Huang, W.; Bonal, D.M.; Liu, J.; Dhaneshwar, A.; DePeaux, K.; Gowaski, M.R.; et al. The Combined Effect of FGFR Inhibition and PD-1 Blockade Promotes Tumor-Intrinsic Induction of Antitumor Immunity. Cancer Immunol. Res. 2019, 7, 1457-1471. [CrossRef]

131. Holmstrom, T.H.; Moilanen, A.M.; Ikonen, T.; Bjorkman, M.L.; Linnanen, T.; Wohlfahrt, G.; Karlsson, S.; Oksala, R.; Korjamo, T.; Samajdar, S.; et al. ODM-203, a Selective Inhibitor of FGFR and VEGFR, Shows Strong Antitumor Activity, and Induces Antitumor Immunity. Mol. Cancer Ther. 2019, 18, 28-38. [CrossRef]

132. Deng, H.; Kan, A.; Lyu, N.; Mu, L.; Han, Y.; Liu, L.; Zhang, Y.; Duan, Y.; Liao, S.; Li, S.; et al. Dual Vascular Endothelial Growth Factor Receptor and Fibroblast Growth Factor Receptor Inhibition Elicits Antitumor Immunity and Enhances Programmed Cell Death-1 Checkpoint Blockade in Hepatocellular Carcinoma. Liver Cancer 2020, 9, 338-357. [CrossRef] 
133. Glorieux, C.; Xia, X.; He, Y.Q.; Hu, Y.; Cremer, K.; Robert, A.; Liu, J.; Wang, F.; Ling, J.; Chiao, P.J.; et al. Regulation of PD-L1 expression in K-ras-driven cancers through ROS-mediated FGFR1 signaling. Redox Biol. 2021, 38, 101780. [CrossRef]

134. Akhand, S.S.; Liu, Z.; Purdy, S.C.; Abdullah, A.; Lin, H.; Cresswell, G.M.; Ratliff, T.L.; Wendt, M. Pharmacologic Inhibition of FGFR Modulates the Metastatic Immune Microenvironment and Promotes Response to Immune Checkpoint Blockade. Cancer Immunol. Res. 2020, 8, 1542-1553. [CrossRef]

135. Siefker-Radtke, A.O.; Necchi, A.; Rosenbaum, E.; Culine, S.; Burgess, E.F.; O’Donnell, P.H.; Tagawa, S.T.; Zakharia, Y.; OHagan, A.; Avadhani, A.N.; et al. Efficacy of programmed death 1 (PD-1) and programmed death 1 ligand (PD-L1) inhibitors in patients with FGFR mutations and gene fusions: Results from a data analysis of an ongoing phase 2 study of erdafitinib (JNJ-42756493) in patients (pts) with advanced urothelial cancer (UC). J. Clin. Oncol. 2018, 36, 450.

136. Wang, L.; Gong, Y.; Saci, A.; Szabo, P.M.; Martini, A.; Necchi, A.; Siefker-Radtke, A.; Pal, S.; Plimack, E.R.; Sfakianos, J.P.; et al. Fibroblast Growth Factor Receptor 3 Alterations and Response to PD-1/PD-L1 Blockade in Patients with Metastatic Urothelial Cancer. Eur. Urol. 2019, 76, 599-603. [CrossRef] [PubMed]

137. Kacew, A.; Sweis, R.F. FGFR3 Alterations in the Era of Immunotherapy for Urothelial Bladder Cancer. Front. Immunol 2020, 11, 575258. [CrossRef] [PubMed]

138. Katoh, M. Fibroblast growth factor receptors as treatment targets in clinical oncology. Nat. Rev. Clin. Oncol. 2019, 16, 105-122. [CrossRef]

139. Taylor, M.H.; Schmidt, E.V.; Dutcus, C.; Pinheiro, E.M.; Funahashi, Y.; Lubiniecki, G.; Rasco, D. The LEAP program: Lenvatinib plus pembrolizumab for the treatment of advanced solid tumors. Future Oncol. 2021, 17, 637-648. [CrossRef] [PubMed]

140. Akbay, E.A.; Koyama, S.; Carretero, J.; Altabef, A.; Tchaicha, J.H.; Christensen, C.L.; Mikse, O.R.; Cherniack, A.D.; Beauchamp, E.M.; Pugh, T.J.; et al. Activation of the PD-1 pathway contributes to immune escape in EGFR-driven lung tumors. Cancer Discov. 2013, 3, 1355-1363. [CrossRef] [PubMed]

141. Abdelhamed, S.; Ogura, K.; Yokoyama, S.; Saiki, I.; Hayakawa, Y. AKT-STAT3 Pathway as a Downstream Target of EGFR Signaling to Regulate PD-L1 Expression on NSCLC cells. J. Cancer 2016, 7, 1579-1586. [CrossRef]

142. Okita, R.; Maeda, A.; Shimizu, K.; Nojima, Y.; Saisho, S.; Nakata, M. PD-L1 overexpression is partially regulated by EGFR/HER2 signaling and associated with poor prognosis in patients with non-small-cell lung cancer. Cancer Immunol. Immunother. 2017, 66, 865-876. [CrossRef]

143. Stutvoet, T.S.; Kol, A.; de Vries, E.G.; de Bruyn, M.; Fehrmann, R.S.; Terwisscha van Scheltinga, A.G.; de Jong, S. MAPK pathway activity plays a key role in PD-L1 expression of lung adenocarcinoma cells. J. Pathol. 2019, 249, 52-64. [CrossRef] [PubMed]

144. Wang, S.; Xu, L.; Che, X.; Li, C.; Xu, L.; Hou, K.; Fan, Y.; Wen, T.; Qu, X.; Liu, Y. E3 ubiquitin ligases Cbl-b and c-Cbl downregulate PD-L1 in EGFR wild-type non-small cell lung cancer. FEBS Lett. 2018, 592, 621-630. [CrossRef]

145. Zhang, N.; Zeng, Y.; Du, W.; Zhu, J.; Shen, D.; Liu, Z.; Huang, J.A. The EGFR pathway is involved in the regulation of PD-L1 expression via the IL-6/JAK/STAT3 signaling pathway in EGFR-mutated non-small cell lung cancer. Int. J. Oncol. 2016, 49, 1360-1368. [CrossRef]

146. Jiang, X.M.; Xu, Y.L.; Huang, M.Y.; Zhang, L.L.; Su, M.X.; Chen, X.; Lu, J.J. Osimertinib (AZD9291) decreases programmed death ligand-1 in EGFR-mutated non-small cell lung cancer cells. Acta Pharmacol. Sin. 2017, 38, 1512-1520. [CrossRef]

147. Concha-Benavente, F.; Srivastava, R.M.; Trivedi, S.; Lei, Y.; Chandran, U.; Seethala, R.R.; Freeman, G.J.; Ferris, R.L. Identification of the Cell-Intrinsic and -Extrinsic Pathways Downstream of EGFR and IFNgamma That Induce PD-L1 Expression in Head and Neck Cancer. Cancer Res. 2016, 76, 1031-1043. [CrossRef] [PubMed]

148. Ng, H.Y.; Li, J.; Tao, L.; Lam, A.K.; Chan, K.W.; Ko, J.M.Y.; Yu, V.Z.; Wong, M.; Li, B.; Lung, M.L. Chemotherapeutic Treatments Increase PD-L1 Expression in Esophageal Squamous Cell Carcinoma through EGFR/ERK Activation. Transl. Oncol. 2018, 11, 1323-1333. [CrossRef] [PubMed]

149. Zhang, W.; Pang, Q.; Yan, C.; Wang, Q.; Yang, J.; Yu, S.; Liu, X.; Yuan, Z.; Wang, P.; Xiao, Z. Induction of PD-L1 expression by epidermal growth factor receptor-mediated signaling in esophageal squamous cell carcinoma. Onco Targets Ther. 2017, 10, 763-771. [CrossRef]

150. Suh, K.J.; Sung, J.H.; Kim, J.W.; Han, S.H.; Lee, H.S.; Min, A.; Kang, M.H.; Kim, J.E.; Kim, J.W.; Kim, S.H.; et al. EGFR or HER2 inhibition modulates the tumor microenvironment by suppression of PD-L1 and cytokines release. Oncotarget 2017, 8, 63901-63910. [CrossRef]

151. Wang, Y.; Hu, J.; Wang, Y.; Ye, W.; Zhang, X.; Ju, H.; Xu, D.; Liu, L.; Ye, D.; Zhang, L.; et al. EGFR activation induced Snaildependent EMT and myc-dependent PD-L1 in human salivary adenoid cystic carcinoma cells. Cell Cycle 2018, 17, 1457-1470. [CrossRef] [PubMed]

152. Cheng, C.C.; Lin, H.C.; Tsai, K.J.; Chiang, Y.W.; Lim, K.H.; Chen, C.G.; Su, Y.W.; Peng, C.L.; Ho, A.S.; Huang, L.; et al. Epidermal growth factor induces STAT1 expression to exacerbate the IFNr-mediated PD-L1 axis in epidermal growth factor receptor-positive cancers. Mol. Carcinog. 2018, 57, 1588-1598. [CrossRef] [PubMed]

153. Li, T.; Zhang, C.; Zhao, G.; Zhang, X.; Hao, M.; Hassan, S.; Zhang, M.; Zheng, H.; Yang, D.; Liu, L.; et al. IGFBP2 regulates PD-L1 expression by activating the EGFR-STAT3 signaling pathway in malignant melanoma. Cancer Lett. 2020, 477, 19-30. [CrossRef] [PubMed]

154. Su, L.; Guo, W.; Lou, L.; Nie, S.; Zhang, Q.; Liu, Y.; Chang, Y.; Zhang, X.; Li, Y.; Shen, H. EGFR-ERK pathway regulates CSN6 to contribute to PD-L1 expression in glioblastoma. Mol. Carcinog. 2020, 59, 520-532. [CrossRef] [PubMed] 
155. Ma, G.; Liang, Y.; Chen, Y.; Wang, L.; Li, D.; Liang, Z.; Wang, X.; Tian, D.; Yang, X.; Niu, H. Glutamine Deprivation Induces PD-L1 Expression via Activation of EGFR/ERK/c-Jun Signaling in Renal Cancer. Mol. Cancer Res. 2020, 18, 324-339. [CrossRef] [PubMed]

156. D’Incecco, A.; Andreozzi, M.; Ludovini, V.; Rossi, E.; Capodanno, A.; Landi, L.; Tibaldi, C.; Minuti, G.; Salvini, J.; Coppi, E.; et al. PD-1 and PD-L1 expression in molecularly selected non-small-cell lung cancer patients. Br. J. Cancer 2015, 112, 95-102. [CrossRef]

157. Lin, K.; Cheng, J.; Yang, T.; Li, Y.; Zhu, B. EGFR-TKI down-regulates PD-L1 in EGFR mutant NSCLC through inhibiting NF-kappaB. Biochem. Biophys. Res. Commun. 2015, 463, 95-101. [CrossRef]

158. Li, M.; Liu, F.; Zhang, F.; Zhou, W.; Jiang, X.; Yang, Y.; Qu, K.; Wang, Y.; Ma, Q.; Wang, T.; et al. Genomic ERBB2/ERBB3 mutations promote PD-L1-mediated immune escape in gallbladder cancer: A whole-exome sequencing analysis. Gut 2019, 68, 1024-1033. [CrossRef]

159. To, K.K.W.; Fong, W.; Cho, W.C.S. Immunotherapy in Treating EGFR-Mutant Lung Cancer: Current Challenges and New Strategies. Front. Oncol. 2021, 11, 635007. [CrossRef]

160. Gavralidis, A.; Gainor, J.F. Immunotherapy in EGFR-Mutant and ALK-Positive Lung Cancer: Implications for Oncogene-Driven Lung Cancer. Cancer J. 2020, 26, 517-524. [CrossRef]

161. Liang, H.; Liu, X.; Wang, M. Immunotherapy combined with epidermal growth factor receptor-tyrosine kinase inhibitors in non-small-cell lung cancer treatment. Onco Targets Ther. 2018, 11, 6189-6196. [CrossRef] [PubMed]

162. Durand-Panteix, S.; Farhat, M.; Youlyouz-Marfak, I.; Rouaud, P.; Ouk-Martin, C.; David, A.; Faumont, N.; Feuillard, J.; JayatVignoles, C. B7-H1, which represses EBV-immortalized B cell killing by autologous T and NK cells, is oppositely regulated by c-Myc and EBV latency III program at both mRNA and secretory lysosome levels. J. Immunol. 2012, 189, 181-190. [CrossRef] [PubMed]

163. Zou, J.; Zhuang, M.; Yu, X.; Li, N.; Mao, R.; Wang, Z.; Wang, J.; Wang, X.; Zhou, H.; Zhang, L.; et al. MYC inhibition increases PD-L1 expression induced by IFN-gamma in hepatocellular carcinoma cells. Mol. Immunol. 2018, 101, 203-209. [CrossRef] [PubMed]

164. Schuhmacher, B.; Rengstl, B.; Doring, C.; Bein, J.; Newrzela, S.; Brunnberg, U.; Kvasnicka, H.M.; Vornanen, M.; Kuppers, R.; Hansmann, M.L.; et al. A strong host response and lack of MYC expression are characteristic for diffuse large B cell lymphoma transformed from nodular lymphocyte predominant Hodgkin lymphoma. Oncotarget 2016, 7, 72197-72210. [CrossRef]

165. Han, H.; Jain, A.D.; Truica, M.I.; Izquierdo-Ferrer, J.; Anker, J.F.; Lysy, B.; Sagar, V.; Luan, Y.; Chalmers, Z.R.; Unno, K.; et al. Small-Molecule MYC Inhibitors Suppress Tumor Growth and Enhance Immunotherapy. Cancer Cell 2019, 36, 483-497. [CrossRef]

166. Fusello, A.; Horowitz, J.; Yang-Iott, K.; Brady, B.L.; Yin, B.; Rowh, M.A.; Rappaport, E.; Bassing, C.H. Histone H2AX suppresses translocations in lymphomas of Emu-c-Myc transgenic mice that contain a germline amplicon of tumor-promoting genes. Cell Cycle 2013, 12, 2867-2875. [CrossRef]

167. Kharma, B.; Baba, T.; Matsumura, N.; Kang, H.S.; Hamanishi, J.; Murakami, R.; McConechy, M.M.; Leung, S.; Yamaguchi, K.; Hosoe, Y.; et al. STAT1 drives tumor progression in serous papillary endometrial cancer. Cancer Res. 2014, 74, 6519-6530. [CrossRef]

168. Atsaves, V.; Tsesmetzis, N.; Chioureas, D.; Kis, L.; Leventaki, V.; Drakos, E.; Panaretakis, T.; Grander, D.; Medeiros, L.J.; Young, K.H.; et al. PD-L1 is commonly expressed and transcriptionally regulated by STAT3 and MYC in ALK-negative anaplastic large-cell lymphoma. Leukemia 2017, 31, 1633-1637. [CrossRef]

169. Sun, L.; Wang, Q.; Chen, B.; Zhao, Y.; Shen, B.; Wang, H.; Xu, J.; Zhu, M.; Zhao, X.; Xu, C.; et al. Gastric cancer mesenchymal stem cells derived IL-8 induces PD-L1 expression in gastric cancer cells via STAT3/mTOR-c-Myc signal axis. Cell Death Dis. 2018, 9, 928. [CrossRef]

170. Wang, J.; Jia, Y.; Zhao, S.; Zhang, X.; Wang, X.; Han, X.; Wang, Y.; Ma, M.; Shi, J.; Liu, L. BIN1 reverses PD-L1-mediated immune escape by inactivating the c-MYC and EGFR/MAPK signaling pathways in non-small cell lung cancer. Oncogene 2017, 36, 6235-6243. [CrossRef]

171. Melaiu, O.; Mina, M.; Chierici, M.; Boldrini, R.; Jurman, G.; Romania, P.; D'Alicandro, V.; Benedetti, M.C.; Castellano, A.; Liu, T.; et al. PD-L1 Is a Therapeutic Target of the Bromodomain Inhibitor JQ1 and, Combined with HLA Class I, a Promising Prognostic Biomarker in Neuroblastoma. Clin. Cancer Res. 2017, 23, 4462-4472. [CrossRef]

172. Kim, E.Y.; Kim, A.; Kim, S.K.; Chang, Y.S. MYC expression correlates with PD-L1 expression in non-small cell lung cancer. Lung Cancer 2017, 110, 63-67. [CrossRef]

173. Pan, Y.; Fei, Q.; Xiong, P.; Yang, J.; Zhang, Z.; Lin, X.; Pan, M.; Lu, F.; Huang, H. Synergistic inhibition of pancreatic cancer with anti-PD-L1 and c-Myc inhibitor JQ1. Oncoimmunology 2019, 8, e1581529. [CrossRef] [PubMed]

174. Liang, M.Q.; Yu, F.Q.; Chen, C. C-Myc regulates PD-L1 expression in esophageal squamous cell carcinoma. Am. J. Transl. Res. 2020, 12, 379-388. [PubMed]

175. Kortlever, R.M.; Sodir, N.M.; Wilson, C.H.; Burkhart, D.L.; Pellegrinet, L.; Brown Swigart, L.; Littlewood, T.D.; Evan, G.I. Myc Cooperates with Ras by Programming Inflammation and Immune Suppression. Cell 2017, 171, 1301-1315. [CrossRef] [PubMed]

176. Xu, Y.; Poggio, M.; Jin, H.Y.; Shi, Z.; Forester, C.M.; Wang, Y.; Stumpf, C.R.; Xue, L.; Devericks, E.; So, L.; et al. Translation control of the immune checkpoint in cancer and its therapeutic targeting. Nat. Med. 2019, 25, 301-311. [CrossRef] [PubMed]

177. Xue, T.; Wang, W.G.; Zhou, X.Y.; Li, X.Q. EBV-positive diffuse large B-cell lymphoma features PD-L1 protein but not mRNA overexpression. Pathology 2018, 50, 725-729. [CrossRef]

178. Soussi, T.; Wiman, K.G. TP53: An oncogene in disguise. Cell Death Differ. 2015, 22, 1239-1249. [CrossRef] [PubMed] 
179. Kan, G.; Dong, W. The expression of PD-L1 APE1 and P53 in hepatocellular carcinoma and its relationship to clinical pathology. Eur. Rev. Med. Pharmacol. Sci. 2015, 19, 3063-3071. [PubMed]

180. Cortez, M.A.; Ivan, C.; Valdecanas, D.; Wang, X.; Peltier, H.J.; Ye, Y.; Araujo, L.; Carbone, D.P.; Shilo, K.; Giri, D.K.; et al. PDL1 Regulation by 553 via miR-34. J. Natl. Cancer Inst. 2016, 108, djv303. [CrossRef]

181. Braun, M.W.; Iwakuma, T. Regulation of cytotoxic T-cell responses by p53 in cancer. Transl. Cancer Res. 2016, 5, 692-697. [CrossRef] [PubMed]

182. Hashimoto, S.; Furukawa, S.; Hashimoto, A.; Tsutaho, A.; Fukao, A.; Sakamura, Y.; Parajuli, G.; Onodera, Y.; Otsuka, Y.; Handa, H.; et al. ARF6 and AMAP1 are major targets of KRAS and TP53 mutations to promote invasion, PD-L1 dynamics, and immune evasion of pancreatic cancer. Proc. Natl. Acad. Sci. USA 2019, 116, 17450-17459. [CrossRef] [PubMed]

183. Chen, J.; Zhou, J.; Fu, H.; Ni, X.; Shan, Y. Upregulation of oxidative stress-responsive 1(OXSR1) predicts poor prognosis and promotes hepatocellular carcinoma progression. Bioengineered 2020, 11, 958-971. [CrossRef] [PubMed]

184. Thiem, A.; Hesbacher, S.; Kneitz, H.; di Primio, T.; Heppt, M.V.; Hermanns, H.M.; Goebeler, M.; Meierjohann, S.; Houben, R.; Schrama, D. IFN-gamma-induced PD-L1 expression in melanoma depends on p53 expression. J. Exp. Clin. Cancer Res. 2019, 38, 397. [CrossRef]

185. Assoun, S.; Theou-Anton, N.; Nguenang, M.; Cazes, A.; Danel, C.; Abbar, B.; Pluvy, J.; Gounant, V.; Khalil, A.; Namour, C.; et al. Association of TP53 mutations with response and longer survival under immune checkpoint inhibitors in advanced non-small-cell lung cancer. Lung Cancer 2019, 132, 65-71. [CrossRef] [PubMed]

186. Sun, H.; Liu, S.Y.; Zhou, J.Y.; Xu, J.T.; Zhang, H.K.; Yan, H.H.; Huan, J.J.; Dai, P.P.; Xu, C.R.; Su, J.; et al. Specific TP53 subtype as biomarker for immune checkpoint inhibitors in lung adenocarcinoma. EBioMedicine 2020, 60, 102990. [CrossRef]

187. Zhou, X.; Singh, M.; Sanz Santos, G.; Guerlavais, V.; Carvajal, L.A.; Aivado, M.; Zhan, Y.; Oliveira, M.M.S.; Westerberg, L.S.; Annis, D.A.; et al. Pharmacological activation of p53 triggers viral mimicry response thereby abolishing tumor immune evasion and promoting anti-tumor immunity. Cancer Discov. 2021. [CrossRef]

188. Koh, J.; Jang, J.Y.; Keam, B.; Kim, S.; Kim, M.Y.; Go, H.; Kim, T.M.; Kim, D.W.; Kim, C.W.; Jeon, Y.K.; et al. EML4-ALK enhances programmed cell death-ligand 1 expression in pulmonary adenocarcinoma via hypoxia-inducible factor (HIF)-1alpha and STAT3. Oncoimmunology 2016, 5, e1108514. [CrossRef]

189. Ota, K.; Azuma, K.; Kawahara, A.; Hattori, S.; Iwama, E.; Tanizaki, J.; Harada, T.; Matsumoto, K.; Takayama, K.; Takamori, S.; et al. Induction of PD-L1 Expression by the EML4-ALK Oncoprotein and Downstream Signaling Pathways in Non-Small Cell Lung Cancer. Clin. Cancer Res. 2015, 21, 4014-4021. [CrossRef]

190. Hong, S.; Chen, N.; Fang, W.; Zhan, J.; Liu, Q.; Kang, S.; He, X.; Liu, L.; Zhou, T.; Huang, J.; et al. Upregulation of PD-L1 by EML4-ALK fusion protein mediates the immune escape in ALK positive NSCLC: Implication for optional anti-PD-1/PD-L1 immune therapy for ALK-TKIs sensitive and resistant NSCLC patients. Oncoimmunology 2016, 5, e1094598. [CrossRef]

191. Guaitoli, G.; Tiseo, M.; Di Maio, M.; Friboulet, L.; Facchinetti, F. Immune checkpoint inhibitors in oncogene-addicted non-small cell lung cancer: A systematic review and meta-analysis. Transl. Lung Cancer Res. 2021, 10, 2890-2916. [CrossRef]

192. Sankar, K.; Nagrath, S.; Ramnath, N. Immunotherapy for ALK-Rearranged Non-Small Cell Lung Cancer: Challenges Inform Promising Approaches. Cancers 2021, 13, 1476. [CrossRef] [PubMed]

193. Wang, L.; Lui, V.W.Y. Emerging Roles of ALK in Immunity and Insights for Immunotherapy. Cancers 2020, 12, 426. [CrossRef] [PubMed]

194. Sumimoto, H.; Takano, A.; Teramoto, K.; Daigo, Y. RAS-Mitogen-Activated Protein Kinase Signal Is Required for Enhanced PD-L1 Expression in Human Lung Cancers. PLoS ONE 2016, 11, e0166626. [CrossRef] [PubMed]

195. Chen, N.; Fang, W.; Lin, Z.; Peng, P.; Wang, J.; Zhan, J.; Hong, S.; Huang, J.; Liu, L.; Sheng, J.; et al. KRAS mutation-induced upregulation of PD-L1 mediates immune escape in human lung adenocarcinoma. Cancer Immunol. Immunother. 2017, 66, 1175-1187. [CrossRef]

196. Lee, M.H.; Yanagawa, J.; Tran, L.; Walser, T.C.; Bisht, B.; Fung, E.; Park, S.J.; Zeng, G.; Krysan, K.; Wallace, W.D.; et al. FRA1 contributes to MEK-ERK pathway-dependent PD-L1 upregulation by KRAS mutation in premalignant human bronchial epithelial cells. Am. J. Transl. Res. 2020, 12, 409-427.

197. Lastwika, K.J.; Wilson, W., 3rd; Li, Q.K.; Norris, J.; Xu, H.; Ghazarian, S.R.; Kitagawa, H.; Kawabata, S.; Taube, J.M.; Yao, S.; et al. Control of PD-L1 Expression by Oncogenic Activation of the AKT-mTOR Pathway in Non-Small Cell Lung Cancer. Cancer Res. 2016, 76, 227-238. [CrossRef] [PubMed]

198. Weng, C.C.; Hsieh, M.J.; Wu, C.C.; Lin, Y.C.; Shan, Y.S.; Hung, W.C.; Chen, L.T.; Cheng, K.H. Loss of the transcriptional repressor TGIF1 results in enhanced Kras-driven development of pancreatic cancer. Mol. Cancer 2019, 18, 96. [CrossRef]

199. Coelho, M.A.; de Carne Trecesson, S.; Rana, S.; Zecchin, D.; Moore, C.; Molina-Arcas, M.; East, P.; Spencer-Dene, B.; Nye, E.; Barnouin, K.; et al. Oncogenic RAS Signaling Promotes Tumor Immunoresistance by Stabilizing PD-L1 mRNA. Immunity 2017, 47, 1083-1099. [CrossRef]

200. Booth, L.; Roberts, J.L.; Sander, C.; Lalani, A.S.; Kirkwood, J.M.; Hancock, J.F.; Poklepovic, A.; Dent, P. Neratinib and entinostat combine to rapidly reduce the expression of K-RAS, N-RAS, Galphaq and Galpha11 and kill uveal melanoma cells. Cancer Biol. Ther. 2019, 20, 700-710. [CrossRef]

201. Bowers, N.L.; Helton, E.S.; Huijbregts, R.P.; Goepfert, P.A.; Heath, S.L.; Hel, Z. Immune suppression by neutrophils in HIV-1 infection: Role of PD-L1/PD-1 pathway. PLoS Pathog. 2014, 10, e1003993. [CrossRef] 
202. Khou, S.; Popa, A.; Luci, C.; Bihl, F.; Meghraoui-Kheddar, A.; Bourdely, P.; Salavagione, E.; Cosson, E.; Rubod, A.; Cazareth, J.; et al. Tumor-Associated Neutrophils Dampen Adaptive Immunity and Promote Cutaneous Squamous Cell Carcinoma Development. Cancers 2020, 12, 1860. [CrossRef]

203. Tung, J.N.; Lin, P.L.; Wang, Y.C.; Wu, D.W.; Chen, C.Y.; Lee, H. PD-L1 confers resistance to EGFR mutation-independent tyrosine kinase inhibitors in non-small cell lung cancer via upregulation of YAP1 expression. Oncotarget 2018, 9, 4637-4646. [CrossRef]

204. Vokalova, L.; Balogh, A.; Toth, E.; Van Breda, S.V.; Schafer, G.; Hoesli, I.; Lapaire, O.; Hahn, S.; Than, N.G.; Rossi, S.W. Placental Protein 13 (Galectin-13) Polarizes Neutrophils Toward an Immune Regulatory Phenotype. Front Immunol. 2020, 11, 145. [CrossRef] [PubMed]

205. Wangpaichitr, M.; Kandemir, H.; Li, Y.Y.; Wu, C.; Nguyen, D.; Feun, L.G.; Kuo, M.T.; Savaraj, N. Relationship of Metabolic Alterations and PD-L1 Expression in Cisplatin Resistant Lung Cancer. Cell Dev. Biol. 2017, 6, 183. [PubMed]

206. Zheng, X.; Chen, Y.; Bai, M.; Liu, Y.; Xu, B.; Sun, R.; Zeng, H. The antimetastatic effect and underlying mechanisms of thioredoxin reductase inhibitor ethaselen. Free Radic. Biol. Med. 2019, 131, 7-17. [CrossRef]

207. Zhu, G.; Li, X.; Li, J.; Zhou, W.; Chen, Z.; Fan, Y.; Jiang, Y.; Zhao, Y.; Sun, G.; Mao, W. Arsenic trioxide (ATO) induced degradation of Cyclin D1 sensitized PD-1/PD-L1 checkpoint inhibitor in oral and esophageal squamous cell carcinoma. J. Cancer 2020, 11, 6516-6529. [CrossRef] [PubMed]

208. Bailly, C. Regulation of PD-L1 expression on cancer cells with ROS-modulating drugs. Life Sci. 2020, 246, 117403. [CrossRef]

209. Gilardini Montani, M.S.; Santarelli, R.; Falcinelli, L.; Gonnella, R.; Granato, M.; Di Renzo, L.; Cuomo, L.; Vitillo, M.; Faggioni, A.; Cirone, M. EBV up-regulates PD-L1 on the surface of primary monocytes by increasing ROS and activating TLR signaling and STAT3. J. Leukoc. Biol. 2018, 104, 821-832. [CrossRef] [PubMed]

210. Romeo, M.A.; Gilardini Montani, M.S.; Benedetti, R.; Giambelli, L.; D'Aprile, R.; Gaeta, A.; Faggioni, A.; Cirone, M. The cross-talk between STAT1/STAT3 and ROS up-regulates PD-L1 and promotes the release of pro-inflammatory/immune suppressive cytokines in primary monocytes infected by HHV-6B. Virus Res. 2020, 292, 198231. [CrossRef] [PubMed]

211. Roux, C.; Jafari, S.M.; Shinde, R.; Duncan, G.; Cescon, D.W.; Silvester, J.; Chu, M.F.; Hodgson, K.; Berger, T.; Wakeham, A.; et al. Reactive oxygen species modulate macrophage immunosuppressive phenotype through the up-regulation of PD-L1. Proc. Natl. Acad. Sci. USA 2019, 116, 4326-4335. [CrossRef] [PubMed]

212. Glorieux, C.; Cui, L.; Zeng, P.; Xia, X.; Huang, P. Diverse effects of chemotherapeutic agents on immune cell function and implications in immunochemotherapy. Cancer Commun. 2021, 41, 432-435. [CrossRef] [PubMed] 